\title{
Group Effects on Individual Attitudes Toward Social Responsibility
}

\author{
Davide Secchi $^{1} \cdot$ Hong T. M. Bui ${ }^{2,3}$
}

Received: 28 May 2014/ Accepted: 9 October 2015/Published online: 15 March 2016

(c) The Author(s) 2016. This article is published with open access at Springerlink.com

\begin{abstract}
This study uses a quasi-experimental design to investigate what happens to individual socially responsible attitudes when they are exposed to group dynamics. Findings show that group engagement increases individual attitudes toward social responsibility. We also found that individuals with low attitudes toward social responsibility are more likely to change their opinions when group members show more positive attitudes toward social responsibility. Conversely, individuals with high attitudes do not change much, independent of group characteristics. To better analyze the effect of group dynamics, the study proposes to split social responsibility into relative and absolute components. Findings show that relative social responsibility is correlated with but different from absolute social responsibility although the latter is more susceptible than the former to group dynamics.
\end{abstract}

Keywords Individual social responsibility - Absolute and relative social responsibility - Group dynamic .

Socialization - Attitudes toward social responsibility

Davide Secchi

secchi.davi@gmail.com; secchi@sdu.dk

Hong T. M. Bui

hong.bui@soton.ac.uk

1 COMAC Research Cluster, Centre for Human Interactivity (CHI), Department of Language and Communication, University of Southern Denmark, Sdr. Stationvej 28, 4200 Slagelse, Denmark

2 Southampton Management School, University of Southampton, Highfield, Southampton SO17 1BJ, UK

3 VNUK Insitute, University of Danang, Danang, Vietnam

\author{
Abbreviations \\ ACM Attitude change measurement \\ AGSR SR After group activities \\ ANOVA Analysis of variance \\ BGSR SR Before group activities \\ BIC Bayesian information criterion \\ CFA Confirmatory factor analysis \\ CFI Comparative fit index \\ CSR Corporate social responsibility \\ ICC Inter-correlation coefficient \\ ISR Individual social responsibility \\ MRCM Multilevel Random Coefficient Model \\ OLS Ordinary least squares \\ RMSEA Root mean square error of approximation \\ SR Social responsibility \\ SRMR Standardized root mean square residual \\ WOGA Weight of group activities
}

Social responsibility (SR) has been traditionally associated with different perspectives, such as the traditional theory of the firm (Lim and Phillips 2008; McWilliams and Siegel 2011; Ormiston and Wong 2013), stakeholders (Freeman and Liedtka 1991; Hillenbrand et al. 2011), stewardship (Van Dierendonck 2011), sustainability (Gully et al. 2013; Van Marrewijk 2003), corporate citizenship (Glavas and Piderit 2009; Küskü and Zarkada-Fraser 2004), recruitment (Greening and Turban 2000; Jones et al. 2014), job satisfaction (Bauman and Skitka 2012), and many more. The majority of these perspectives address the so-called corporate or organizational level of analysis (Bondy and Starkey 2012; Carroll and Shabana 2010). Traditionally, the study of SR has been concerned with the relations between businesses and the external environment, as most 
of the reviews of the literature seem to suggest (Carroll and Shabana 2010; Garriga and Melé 2004; Secchi 2007). In other words, it studies the position and behavior of the organization as a whole. In contrast, socially responsible perceptions and behavior of agents within organizations featured less prominently in the literature, as already highlighted by Aguinis and Glavas (2012) and earlier by Windsor (2001). Although still less studied than the former, research on this latter aspect of SR is growing (e.g., Aguilera et al. 2007; Rupp 2011; Rupp et al. 2013) and can be referred to as individual SR (ISR). This stream of research is concerned with the way individuals perceive organizational social responsibility (e.g., Greening and Turban 2000; Garcia de los Salmones et al. 2005) and with what characterizes them as socially responsible persons (e.g., Crilly et al. 2008; Secchi 2009).

In a business environment, SR is often considered, implemented, and processed into procedures and routines, or even incorporated into the company's strategy by individuals. It is the company's executives, managers, and employees who make decisions on various aspects of SR (Aguilera et al. 2007; Aguinis and Glavas 2012). A further look at the topic reveals that decisions on SR might also be made collectively by groups/teams (Cappel and Windsor 2000; Rupp et al. 2006; hereafter the words 'group' and 'team' are used interchangeably). In addition, group or team work is increasingly becoming part of regular business and organizational structures (Colquitt et al. 2002; Cropanzano and Schminke 2001). Although groups are key in everyday organizational life, the relationship between SR and group dynamics is yet to be explored. For example, how are individual attitudes toward SR affected by exposure to group activities? Is SR thinking, behavior, and attitude dependent upon the group? Answering these questions will help develop a theory of how group dynamics affect individual SR, and assist further understanding of the role of groups in relation to individual perceptions and behaviors of SR. For the purpose of this study we maintain that ISR reflects a disposition toward making decisions based on a conscious understanding of the consequences that business operations have on both stakeholders and wider society as a whole. This article is concerned with attitudes toward SR, defined consistently with the literature (Gough et al. 1952; Rupp 2011; Sully de Luque et al. 2008) and located under the umbrella of relational theories of SR (Rupp and Mallory 2015; Secchi 2007).

Therefore, moving from 'gap-spotting' to 'path setting' (Alvesson and Sandberg 2011; 2013), we focus on (1) how individual attitudes change when one is exposed to group activities; (2) what the role of the group is when perceptions of SR are considered; and (3) how individuals are affected by group members in formulating opinions on SR. Using a quasi-experimental design we collected data in two waves, one that took place in 2011, the other in 2012.

\section{Theory and Hypotheses Development}

Many studies on SR tend to focus on both ethics and social responsibility together (Carroll and Shabana 2010; Kolodinsky et al. 2010; Singhapakdi et al. 1996). The rationale for this is twofold. SR has firstly emerged from and has been traditionally attached to studies on business ethics and/or business and society (Garriga and Melé 2004; Secchi 2007). For this historical reason, most of the previous studies on individuals do not attempt to isolate ethical from SR perspectives. The other reason concerns the perception that socially irresponsible business practices are somehow understood and studied on moral grounds. This second element derives from the first although it deals more with how scholars frame SR, up to the point where some explicitly refer to 'normative' elements in particular branches of CSR (e.g., in international business-see De George 2000; in normative stakeholder approaches-see Donaldson and Preston 1995). If these two perspectives are the same, then there may be no need to separate them. However, if SR and business ethics describe different but intertwined aspects, we should clearly separate and distinguish between the two. In the following, we try to define individual SR as separate although not completely independent from individual ethical attitudes.

To date, few attempts have been made to identify the different components or antecedents of individual SR (Mudrack 2007; Muller and Kolk 2010; Rupp et al. 2006). Although group socialization mechanisms have been widely studied (Levine and Moreland 1994; Moreland and Levine 2002), and SR research has increasingly covered some aspects at the individual level of analysis (Greening and Gray 1994; Muller and Kolk 2010; Muthuri et al. 2009; Ramus and Steger 2000), we are not aware of many studies that address how group dynamics potentially affect SR. The only exception is that of Mathisen et al. (2013) which investigates how female directors of corporate boards of directors experience boardroom dynamics. Therefore, setting a theoretical framework for research on individual SR and group dynamics is not only 'gap-spotting' but also 'path-setting' (Alvesson and Sandberg 2011; 2013). In doing so, we explore the different components of the SR construct, and demonstrate how they relate to group dynamics and interactions. Figure 1 succinctly summarizes the key elements of the model we are testing and is explained in the following pages.

\section{Attitudes Toward Social Responsibility}

Attitudes toward SR are usually referred to as individual perceptions of general corporate policies to implement social responsibility (or CSR). For example, some authors 


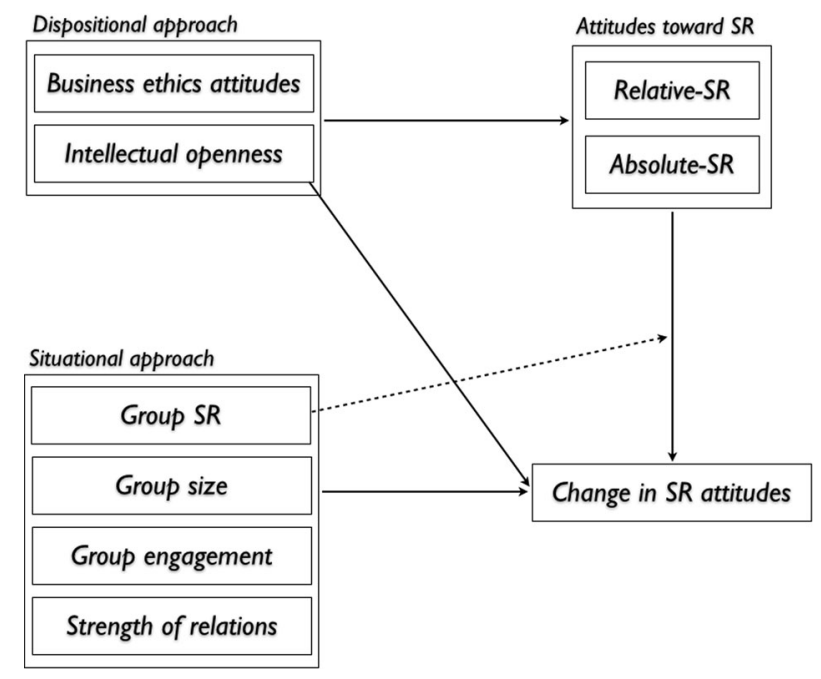

Fig. 1 A theoretical framework for the study of group effects on individual attitudes toward SR

classify them into four types; i.e., economic, legal, ethical, and philanthropic/discretional (Angelidis and Ibrahim 2004; Ibrahim et al. 2008). Some other authors (Rodrigo and Arenas 2008) isolate two types of employee attitudes toward CSR programs: attitudes toward the organization and attitudes toward society. In their 2008 study, Rodrigo and Arenas reveal an attitudinal typology: the committed employee, the indifferent employee, and the dissident employee.

Although this approach is extremely valuable in defining how individual employees perceive their workplace (Gully et al. 2013; Rupp et al. 2013) and provides a practical view on SR, it ignores a more normative or value-based perspective to some extent. Some scholars have long argued for normative elements of certain theories of CSR, such as the stakeholder approach (Donaldson and Preston 1995; Bowie 1991). Others have tried to integrate SR with more ethical (Ormiston and Wong 2013; Singhapakdi et al. 1996) or value-based (Jones et al. 2014) aspects, supporting the idea that there is something more than just a practical aspect to SR.

Before exploring the proposal for a new classification of attitudes toward SR (see below), there is a need to understand what the relation between SR (or ISR), values/principles, and behavior is. On the one hand, ISR relates to other mental frames and states such as cognition (Crilly et al. 2008; Secchi 2009), creativity (Glavas and Piderit 2009), personality (Berkowitz and Lutterman 1968), ethics (Trevino 1986), or justice (Aguilera et al. 2007). From these studies, SR is defined as something that either affects or is derived from a particular set of individual dispositions. In fact, some scholars (in particular the work of Berkowitz and colleagues: Berkowitz and Connor 1966;
Berkowitz and Daniels 1964; Berkowitz and Lutterman 1968) have attempted to define general traits of the socially responsible individual, as if there is a general attitude toward SR that is not related to a specific condition, situation, or environmental constraint. From this perspective, SR can be framed as a mindset that individuals have toward the role (and function) of businesses in society.

On the other hand, SR may eventually have an impact on organizational behavior as it has been related to commitment and identification (Kim et al. 2010), involvement (Jones et al. 2014), job attractiveness (Turban and Greening 1997), satisfaction (Witt and Silver 1994), and personorganization fit (Gully et al. 2013), among other organizational variables (Secchi 2012). In the literature, we could find little evidence that ISR (and its variations) can be interpreted as "behavior," although there is some evidence that it is likely to affect behavior. Under these assumptions, SR can be framed more appropriately as an attitude, i.e., a mental disposition that enables individual (employees, managers, job applicants, and other stakeholders) actions in line with their perception of the organization's overall social responsibility. In other words, the mix of prosocial behaviors that emerge from ISR is in line with one's understanding of the company's role in society. This leads, for example, to job applicants favoring a socially responsible company over a non-socially responsible company (Turban and Greening 1997) or to an increase of employee identification with the organization (Carmeli et al. 2007). In this perspective, ISR can act as a bridge between the perception of the company's policies and individual behavior. In a different but similar conceptualization of ISR, research shows that proactive corporate citizenship positively affects an employee's commitment to the organization (Maignan et al. 1999). Similar results can be found in relation to organizational citizenship behavior and altruism (Jones 2010; Lin et al. 2010). These aspects are clearly related to behavior while the others mentioned above (e.g., organizational attractiveness, identification) lie more at the psycho-cognitive level. Nevertheless, the perception of SR (as it relates to a given company) has been shown to significantly affect several aspects of one's thinking and behavior.

Too little is known on how individuals react to SR, but the evidence we collected seems to highlight that there are two sides to the matter. One is the abstract idea (the values or principles) that an individual has of the role and function of businesses in society; the other is a more pragmatic understanding of the impact of a particular organization on one's thinking and behavior (we may call this orientation). We may also hypothesize a positive match between the first and the second, in the same way norms affect one's intention to behave (e.g., Ajzen 2005). 
In order to capture these nuances of how individuals perceive SR, we suggest that one may have more general or abstract ideas that may or may not necessarily translate into practice. There should be some consistency between the 'general' (absolute) and the 'particular' or 'applied' (relative), as individuals tend to think of themselves as rational beings (Kunda 1999). In other words, we expect a consistent and positive relation between one's ethical or valuebased position and their attitude toward a more 'absolute' perception of SR. However, when individuals deal with practical matters, they may change and adapt their judgment (Payne et al. 1993; Weick and Roberts 1993) more than when they deal with abstractions and generalizations (Ajzen 2005; Magnani 2007). Similarly to what has been argued for ethics (Shawver and Sennetti 2009), we distinguish between relative-SR, that deals with ad hoc situations, problems, and issues, and a more abstract and general absolute-SR, that tends to refer to what one believes all businesses should/must do. There may be some ground to advance a direction in the hypothesized relation between these two aspects of social responsibility. If we hypothesize that reasoning about practical matters or actually doing something is derived from more abstract ideas, we may assume that individuals 'infer' their behavior from higherlevel reasoning. This may be represented as some sort of deductive reasoning. Instead, if we hypothesize that the opposite is the case, and that practical matters help form more general ideas, then we seem to lean toward inductive reasoning. While deduction is mostly advocated by theories of rational choice (e.g., March 1994), induction is more likely to appear when individuals apply bounded rationality (e.g., Secchi 2011). Whether to lean toward the one or the other appears to be, given these two approaches, a matter of which theoretical framework we choose for our study; however, it is likely that these two mechanisms feed on each other. This is more connected to what some have called 'abductive reasoning' (Magnani 2009) or abduction (Pierce 1955), i.e., the generation of explanatory hypotheses based on some empirical evidence. Abduction needs both a certain level of abstraction and experiential reasoning; it is hypothesizing that, for example, publishing an annual social report generates more profits because the company has started to do so since that practice began. There may well be other explanations, though, and this makes this type of abduction particularly "risky" (Thagard 2012). This is the point we are trying to make. In abductive reasoning there is a mix of both practical exposure (or manipulation; see Magnani 2007) and abstractions, so that the hypothesis is generated by the interaction between the two rather than by a specific causal mechanism. Going back to the example above, one's value may be in line with transparent accountability which leads a company to publish an annual social report. In this example, there is an alignment between one's values and what also seem to be the company's values: an increase in profits may be a reflection of the increased role of stakeholders who also value the improved transparency and disclosure in the company's practices (i.e., the annual social report). There are practical elements (e.g., profits, annual report) that merge with and reinforce existing values, although these practical elements are also affected (or biased, we may posit) by the original values. However, a full exploration of these relations does not fall within the main purpose of the current study. Hence, the current study focuses on whether there is a positive correlation between the two concepts, leaving further and more informed hypotheses to future studies:

H1a There is a more practical attitude toward SR, or relative-SR, which is correlated with but different from a more abstract SR attitude, or absolute-SR.

When working in groups, individuals tend to adapt and update their cognition (Cannon-Bowers and Salas 2001) more often than when they deal with a problem in isolation. This suggests that practical implications of a particular issue dealt with by group work helps members to consider it from various perspectives. Those who maintain a strong and abstract understanding of the issue may be less likely to change their mind. Therefore, we argue that there tends to be a stronger prevalence of and adherence to SR values when individuals deal with more abstract and prescriptive concepts than when they face a specific issue or case. Therefore, we hypothesize:

H1b Attitudes toward relative-SR are more likely to change under the effects of group activities as opposed to absolute-SR attitudes.

\section{Situational and Dispositional Approaches to the Attitude Toward Social Responsibility}

Situational and dispositional approaches (Fig. 1) have been well utilized to investigate various human attitudes and behavior. The situational approach refers to the importance of the environmental situation in determining attitudes and behaviors (Goldfried and d'Zurilla 1969), while the dispositional approach refers to personal characteristics and assumptions in explaining individual attitudes and behaviors (Staw and Cohen-Charash 2005). Because these approaches are often considered to oppose one another, few scholars have chosen both approaches in the same study. In contrast, we employ both the situational approach (via group-related factors) and the dispositional approach (via personal characteristics) to provide a more robust understanding of individual attitudes toward SR. That is, in our theoretical framework (Fig. 1), we consider two elements 
that the literature suggests affect individual SR-namely business ethics attitudes (which refers to personal beliefs), and personal characteristics (intellectual openness). These individual attitudes are then considered as a starting point to understand how change in SR attitudes happen when people are exposed to group-related elements (such as group sizes, relationships, group "think," and engagement). These factors are reviewed in the following.

\section{Attitudes Toward Business Ethics}

According to Garriga and Melé (2004), there are SR constructs that specifically examine how ethical beliefs affect behavior. They tend to provide a normative (prescriptive) background for ethics and SR. For this reason, they are named ethical approaches to SR. Mainstream approaches in this field usually refer to macro-phenomena such as normative stakeholder theory (Donaldson and Preston 1995), or theories of human rights integration to the business discourse (Barkemeyer 2009). It is worth noting that theories at the macro-level sometimes inform research at the individual level. Carroll's (1979) pyramid, for example, structures SR in four distinct levels, namely economic, legal, ethical, and discretional responsibilities. These four levels together define and help us to understand the constituent features of SR. More recently, the pyramid has been used to analyze consumer perceptions of organizational SR (Garcia de los Salmones et al. 2005). The operationalization of Carroll's (1979) construct at the individual level highlights how SR is intertwined with economic and ethical responsibilities (Maignan 2001). These studies seem to suggest that SR is positively related to the ethical dimension (Kolodinsky et al. 2010).

Singhapakdi et al. (1996) and Etheredge (1999) argue that there is, respectively, a strict (either) positive or negative correlation between ethical idealism-i.e., an inquiry into the nature and function of ideals (Rescher 1987)relativism-i.e., an acceptance of more than a set of basic normal standard (Lyons 1976) — and participants' perceptions of SR and ethics. Further studies (Kolodinsky et al. 2010; Park 2005) report significant relations between ethics and SR behavior, implying that the former is a pre-condition of the latter. What appears to be particularly striking is that there is a link between individual morality and perceptions of a company's social performance. Also, some socially responsible companies attract job applicants that are already positively pre-disposed toward SR (Turban and Greening 1997). Given this link, we propose the following hypothesis:

H2 Individual attitudes toward business ethics affect one's attitudes toward SR.

\section{Intellectual Openness}

Personal characteristics are defined as stable individual differences that may play a role in relation to one's attitudes toward SR. They may range from gender (Cheah et al. 2011; Greening and Turban 2000) and age (Nakamura and Watanabe-Muraoka 2006) to personality (Lin et al. 2010; Mudrack 2007).

From a different angle, SR has been related to traditional values (Berkowitz and Lutterman 1968) or conservatism (Mudrack 2007) although results are contradictory. We argue that SR is related to more open traits of individual cognition, values, and personality. This is particularly relevant when seeking to understand SR in the context of child development (Harris et al. 1954). It can be argued that the early development of SR remains with us until we are adults (as a chance-seeking activity; see Bardone 2011). The tendency to be open to change and experience as opposed to being 'conservative' can be also framed as intellectual openness (Judge et al. 1999). Drawing on these studies, we claim that the acceptance of SR requires a certain degree of openness for the simple reason that it relates to the external and ever-changing 'social' or environmental dimensions of organizational operations. Otherwise stated, some researches provide evidence that there are traits of personality such as 'openness to experience' that relate positively to socially oriented attitudes and behaviors (Mudrack 2007; Stasio and Capron 1998). Thus, we propose a relationship between intellectual openness and SR attitudes via the following hypothesis:

H3 Intellectual openness positively affects individual SR attitudes.

\section{Group-Related Factors}

Complex and uncertain environments force people to cooperate more, thus groups and teams flourish in today's working environments ( $\mathrm{Li}$ and Cropanzano 2009). Each group establishes specific dynamics that may vary depending on size, individual skills and capabilities, gender composition, social relations between group members, and more (Bettenhausen 1991; Kerr and Tindale 2004). In order to further develop theory in this area, this study establishes a rationale to understand how group dynamics affect SR.

First, group size is an important variable when seeking to understand dynamics and it has been long studied. Groups with larger numbers of people tend to be less efficient in the use of time and resources, but achieve better results (Cohen and Bailey 1997). However, size may only be a moderating factor in the context of this study since larger groups usually hold more stringent expectations in 
terms of social norms and values (Shepperd and Wright 1989). In addition to that, larger groups account for greater deviance among members (Moreland et al. 1996); this means that interactions among members are less frequent (Steiner 1972), conflict becomes more likely (Valacich et al. 1995), and communication quality decreases independent of the means used (Chidambaram and Tung 2005; Lowry et al. 2006). This points to the fact that it may take more time for individual members to be influenced by wider group dynamics. Therefore,

H4 The larger the group size, the less likely it is for individuals to change their attitudes toward SR.

Second, group members may be affected by previous or existing social relationships among each other (Moreland and Levine 2002). Members who know one another and believe there is some level of 'closeness' (e.g., friendship or other relation) may find it easier to either impose their opinion on the group (if it is similar) or to adapt (if dissimilar; Karau and Williams 1993). Knowing each other may also lead group members to develop a 'feel-good' attitude toward the group which makes group work run more smoothly (Levine and Moreland 1990). Given that previous or established knowledge of group members helps people work well together and develop a positive attitude, we argue that this mechanism could influence how members adapt their attitudes toward SR; hence.

H5 The strength of social relationship among group members positively affects the change of SR attitudes.

Finally, engagement (Saks 2006) has been identified as an important element for the analysis of group behavior (Miles and Kivlighan 2012). Engagement can be interpreted as the group member's commitment to actively influence shared knowledge (Miles and Kivlighan 2012; Saks 2006). Group engagement can be related to climate (Colquitt et al. 2002), which is defined as "psychologically meaningful moral descriptions that people can agree characterizes a system's [set of] practices and procedures" (Schneider 1975, p. 474). When work climate is inclusive (Nishii 2013) and it is formulated by group members such that everyone is perceived as making a fair contribution, then performance and outcomes improve (Colquitt et al. 2002). Thus, so-called climate is likely to lead to increased engagement (Miles and Kivlighan 2012) and convergence of how opinions are shared within the group (Moreland and Levine 2002). Thus, we hypothesize:

H6 Higher group engagement increases the likelihood that individual attitudes toward SR change as an effect of group activities.

Drawing on this perspective, group activities may serve as a moderator, with a caveat. We argue that groups develop something called 'tendency toward the mean.' This tendency affects individual beliefs with an impact on members that is similar and depends on (is a function of) how the idea is shared by group members (Levine and Moreland 1990; 2004). In other words, the interactions among group members are vital for any type of group operations (Senge 2006). Hence, group members change or stick to their opinions depending on how group interactions relate to their initial opinion. This leads to the following:

H7a Individuals that highly value SR are more likely to stick to their initial opinion.

H7b Higher levels of group SR positively affect individual change of attitudes toward SR.

\section{Method}

\section{Sample}

The data were collected from final year business students in the UK. A total of 469 students representing 26 nationalities participated in the study. Data were collected in two waves: 276 participants in wave one, year one, and the remaining participants in wave two, year two. The study in year two was an exact replica of that undertaken in year one. Participants were allocated to 105 groups; the average group size in the experiment was $4.59(s d=.81)$. A measure of relationships among participants shows that most of them either have met a few times before, or only met at the university, i.e., participants were mostly unacquainted (mean $=2.64$, $s d=1.12$; the value ' 1 ' never met before to ' 7 ' close friends). The choice of student participants for this particular study is partially justified by the exploratory nature of the study; most of them had held one or more jobs for over one year, had a one-year internship within their business program, and were likely to have experienced group work before (either in business or academic contexts). A very large proportion, $97 \%$ of participants, had work experience (mean $=3.25$ years) in one or more industries (mean $=1.69, s d=.95$ ). Slightly less than half, $47 \%$ of participants were female. The mean age of all participants was $22.4(s d=2.58)$ and the majority, $87 \%$ of respondents, defined themselves as British. To capture the sample's potential differences in ethical values, we asked for religious affiliation and found that $49 \%$ defined themselves as Christian or Catholic, around $2 \%$ as Muslims, and the remaining declared to have no religious affiliation whatsoever. A significant number of participants, $75 \%(s d=.43)$, declared they had a basic understanding of SR, gained from previous university courses.

\section{Design and Procedure}

Participants were briefed on a case. This focused on a large multinational pharmaceutical company that made the 
decision to recall their cleaning solution for contact lenses (Appendix 1). The decision came after a limited number of customers in a few countries-including Singapore, Hong Kong, and the USA-reported loss of vision or suffered serious eye injuries. Participants were not given the final decision, and were asked to offer some alternatives regarding what the company could have done to address the issue.

The procedure was designed to take place in two phases. First, participants were subjected to a survey after the case briefing. The first part of the survey contained a section for personal and demographic data, general SR attitudes, business ethics, and SR related to the case. This part was completed by individual participants. In the second phase, participants were allocated into small groups to discuss the case again. The average time it took the group to complete the assignment was $22.19 \min (s d=9.04)$. After the discussion, participants were asked to answer further questions on group demographics, group activity, and, again, on SR. The time lag between the two phases was one week. It was reasoned that this interval was appropriate in that it was not too short to recall exactly what participants did, and not too long for them to forget about the case.

\section{Measures}

All measures were tested for internal reliability with Cronbach's $\propto$ (Nunnally 1978) and McDonald's $\omega_{h}$ (McDonald 1999). The difference between the way the two indicators are developed suggests that information on the "proportion of scale variance due to a general factor" (Zinbarg et al. 2005, p. 132) is missing when only the traditional $\alpha$ is used. McDonald's $\omega_{h}$ is also described as a (hierarchical) measure of one-factor saturation of a test (Zinbarg et al. 2005). Since the items of many of the scales load on a single general factor, we provide both measures when that is the case. All items for scales used in this study are reported in Appendix 2.

\section{Attitudes Toward Business Ethics}

We used the scale provided by Reidenbach and Robin (1990) to measure general attitudes toward business ethics, making sure that participants referred to the business case when scoring on the items. The scale consists of eight items, assessed on a Likert scale ranging from ' 1 ' to ' 7 ' that asks participants to assess the company's behavior on several issues such as 'fairness', 'moral acceptance,' and 'cultural acceptability.' The scale was measured twice, before and after group discussion. Cronbach's $\alpha$ for the construct is .92 before and .93 after the group exercise. McDonald's $\omega_{h}$ is .83 for this variable.

\section{Attitudes Toward SR}

This variable is measured using two scales, a relative-SR attitude that deals with ad hoc situations, problems, and issues, distinct from a more abstract and general absolute$S R$ that tends to refer to what one believes all businesses should/must do. A measure of the former is provided by adapting the work of Garcia de los Salmones et al. (2005) to the current study. Following these author's footsteps, we used this scale to understand how participants perceived SR relative to a company's behavior. Participants were asked to assess their perception of economic, legal, and ethical responsibilities via three, two, and four items, respectively (Appendix 2). The measure reported a Cronbach's $\alpha$ of .82 and McDonald's $\omega_{h}$ of .78 before group activities and .79 and .70 , respectively, after.

Together with the mini-case, we wanted to test general or absolute attitude toward businesses' SR. The decision to develop a new measure was due to the fact that (a) most SR measures are embedded with ethics measurements, and (b) they are associated with a particular theory or model of CSR. In order to do so, we developed a new multi-item scale using a characteristics checklist, a method often used in applied psychology to measure attitudes or traits (e.g., Ajzen 2005; Watson and Clark 1994). After a review of other measures of SR, we developed a number of items for our list that, following a round of consultation with experts, was reduced to 12 (see Appendix 2 for the full list and to have more details on how the scale was developed). Participants were asked to assess each of the items as core values of any operating businesses using numbers from ' 1 ' to '7', with ' 1 ' being non-existent/irrelevant and ' 7 ' being core value/totally relevant. Absolute-SR is framed as the understanding of the values and principles defining the role (function) of businesses in society. The role or function of business in society has long been used to provide arguments to legitimize or delegitimize CSR, mostly by 'utilitarian' (Secchi 2007) or 'instrumental' (Garriga and Melé 2004) theorists. A famous stance is taken in an article by Milton Friedman in the New York Times Magazine (1970), in which he argued that the only responsibility of business is to maximize its profits. The line of arguments was out of economic and social functionalism. In addition, he answered the question "what is the role of operating businesses" very straightforwardly. For him, the core values of businesses could only be economic or financial, because that is what is needed to fulfill the firm's social role.

That debate is long gone now, although others articulate their reasoning along similar but milder lines (e.g., Porter and Kramer 2002). However, as the literature shows, the debate is no longer as polarized as it was, and scholars 
seem to accept that there are multiple roles and values that companies stand for (e.g., Freeman et al. 2004). To ask participants about the core values of businesses should allow us to understand what the underlying assumptions are that people make about whether businesses should look at some prevalent economic motives or be proactive social agents. In summary, an assessment of the "core values" of businesses should provide a good indication of what participants think the role/function of business is.

In addition, in a standard scale construction, it is extremely important that the objective of the measurement is not too apparent. This is necessary in order to guarantee that subjects are not primed or put in a disposition that is particularly keen on favoring a social desirability (or any other type of) bias (Podsakoff et al. 2012). This is why we considered that referring to "core values" of businesses is a good proxy for understanding what one thinks the role of business in society is. Since we intend to measure social responsibility, the statements we selected for this measure represent items that strictly relate to that literature.

A CFA shows some support for a one-factor model $\left(\chi^{2}=113.87[d f=43], \quad p<.001 ; \quad\right.$ CFI $=.973 ;$ RMSEA $=.059$; SRMR $=.034$; BIC $=329.14)$. We also fitted a three-factor model to the construct $\left(\chi^{2}=\right.$ $123.58[d f=38], p<.001 ; \mathrm{CFI}=.963 ; \mathrm{RMSEA}=.069$; $\mathrm{SRMR}=.038$; $\mathrm{BIC}=295.79)$, grouping items on 'business responsibilities' (items 1, 2, 4, and 11), 'community orientation' (items 5, 6, 7, and 9), and 'good citizenship' (this can also be 'legal responsibilities'; items 3, 8, and 12). Comparing the indices of good fit for the two models, we conclude that the one-factor model is slightly better, although the three-factor model also fits the data well. A Cronbach's $\alpha$ of .90 and .88 and McDonald's $\omega_{h}$ of .74 and .68 , respectively, before and after group 'treatment' were recorded.

We also conducted validity tests to check whether this measure is different from other measures of SR; namely Reidenbach and Robin's (1990) business ethics scale and Garcia de los Salmones et al. (2005)—what we labeled relative-SR scale. We found that Pearson's correlation coefficient with relative-SR and business ethics attitudes is respectively $.228(p<.001)$ and $.029(p=.52)$. Subsequent to exposure to group work, these measures demonstrate similar but weaker patterns of correlation: .119 $(p<.05)$ for absolute- and relative-SR, and -.018 ( $p=.70)$ for business ethics and absolute-SR. Following Farrell (2010), the shared variance (i.e., the amount of variance that one variable explains of another variable) is given by the squared correlation. In our cases, we have .049 prior to and .014 subsequent to group work. After checking for the attenuation-corrected coefficients (Cohen et al. 2003, pp. 56-57), we found enough evidence of discriminant validity for the construct (DeVellis 2012).

\section{Intellectual Openness}

During the first phase, we tested participants for intellectual openness to study whether this attitude relates to either individual SR or its change after group activity. A ten-item scale of intellectual openness from Jackson, Paunonen, and Trembley (2000) was measured on a Likert scale, with values ranging from ' 1 ' strongly disagree to ' 7 ' strongly agree. Cronbach's $\alpha$ for the construct is .69, and McDonald's $\omega_{h}$ is .47 . Despite the second value is low, this measure was tested several times in the psychology literature and we decided to use it in this study.

\section{Group-Related Variables}

Group size was simply assessed by the number of participants that worked in a given group and we also recorded participants' self-reported data for the length of the discussion. The strength of social relationships (or level of acquaintance) among group members was also assessed by asking each participant to rank it on a seven-point scale, with ' 1 ' being never met before, and ' 7 ' being we have always known each other. We used a cumulative measure providing the average strength of social relationships for each participant in respect to their group. Group climate was measured as the level of engagement in the discussion. It was assessed using three items (Appendix 2) on a sevenpoint scale, with ' 1 ' being strongly disagree and ' 7 ' strongly agree. The creation of an ad hoc measure for engagement is due to the particular conditions of the experiment that do not match existing measures of employee engagement (Harter et al. 2002). CFA shows that a one-factor construct fits the data well $\left(\chi^{2}=3.65[d f=2]\right.$, $p=.16 ;$ CFI $=.996 ; \quad \mathrm{RMSEA}=.042 ; \mathrm{SRMR}=.015)$. Coefficient $\alpha$ and McDonald's $\omega_{h}$ for the construct are both .72 .

To capture the impact of group activities on individual attitudes toward SR, we used the weight of group activities (hereafter, WOGA) calculated for each of the measures of SR (i.e., rel, company-related; abs, absolute) and business ethics (be). The WOGA is the difference between individual pre-group and post-group assessments of SR weighted on the difference between emergent group thinking (average SR attitudes of each group member) and the individual pre-group assessment. Both numerator and denominator differences are taken at their absolute value: $\left|S R_{i k 1}-S R_{i k 0}\right| /\left|G-S R_{k}-S R_{i k 0}\right|$, where $S R$ is social responsibility, $i$ is a participant and $k$ indicates the group one is affiliated to at time 0 (pre-group test) and at time 1 (post-group test); and $G-S R$ is the average value of SR attitudes of all group members, i.e., the post-group SR attitudes. A similar calculation has been used in studies of advice discounting (Gino and Moore 2007; Harvey and 
Fisher 1997). When WOGA is 0, it means that group activities registered no impact in the change of individual attitudes toward SR and either one's attitude registered no change at all (the numerator is zero) or the change is not due to the group activities (denominator is zero). If WOGA is $>0$ it means that there has been some change in attitudes and the measure gives a value of SR change that is linked to the group. Assuming that there is a difference in the value of SR between pre- and post-group activities, this value is discounted on the "distance" that the initial SR value $\left(S R_{i k O}\right)$ has on the average group attitudes toward SR $\left(\mathrm{G}-S R_{k}\right)$. This provides a weighted value for change and tells us how much impact the group has had on one's attitude change. Assuming that $\left|S R_{i k 1}-S R_{i k 0}\right|<\mid G$ $S R_{k}-S R_{i k o}$ may mean that a relatively small change in individual attitudes is large compared to the "distance" that the member had to cover to adapt to the group average. Instead, if $\left|S R_{i k 1}-S R_{i k O}\right|>\left|G-S R_{k}-S R_{i k O}\right|$ then the overall change is not entirely due to group activities; instead the member has changed somehow independently from the group. The peculiarity of this equation is that it does not discern positive (upward) from negative (downward) changes but only provides a weight or multiplier factor for the group impact on individual changes in attitude.

The change in individual attitudes is used as a dependent variable to test hypotheses 4-7 and, for this reason, it does not need to be 'discounted' by the group effects. This is done to avoid that the effect of the group in the regression appears as a result of how the dependent variable is constructed. For this reason, it is calculated by post-group $S R$ (AGSR)—pre-group SR (BGSR) divided by the attitude recorded before the group activity (BGSR). We feared that the square of the differences may lead to too much weight on change, thus biasing the results. The formula for attitude change measurement $(A C M)$ is $A C M_{\text {relSR }}=\left(A G S R_{\text {rel }}-\right.$ $\left.B G S R_{r e l}\right) / B G S R_{r e l}$ and $A C M_{a b s S}=\left(A G S R_{a b s}-B G S R_{a b s}\right) /$ $B G S R_{a b s}$

\section{Control and Other Variables}

Most of the coding for the demographic variables was standard: Gender has been coded as ' 1 ' for female and ' 0 ' for male; groups are numbered progressively, from 1 to 105; age is measured in years; nationality is measured as dummy with ' 1 ' being British and ' 0 ' everyone else, due to a smaller number of overseas participants; tenure or seniority is measured in years; and work experience is given by the number of different sectors within which participants worked. Further questions assessed religion (categorical) and previous exposure to $S R$ (also labeled existing CSR knowledge), with ' 1 ' indicating that they were aware and ' 0 ' indicating no awareness of SR. Some of these variables were used as control, others to conduct checks on the data and have a clearer idea of the shape of the sample.

\section{Analytical Strategy}

Eight participants were deleted from the original sample as a result of more than $20 \%$ of missing data in their respective rows; the final sample size is $N=461$. Following Roth (1994) and Cohen et al. (2003), we handled missing data with the aim of preserving standard deviation for each given measure. Therefore, we used mean substitution for missing data up to $2 \%$ and OLS regression for those exceeding $2 \%$ of values in the column (item).

The analytical strategy for the study uses OLS regressions to test hypotheses 2 and 3, where the analysis is not affected by the group. When individual and group effects are nested together so that the independence of observations is violated, the analysis is conducted using a multilevel random coefficient model (MRCM; Hofmann 1997; Raudenbush and Bryk 2002). This technique enables the structuring of the analysis at the individual and group level, and provides better parameter estimation (Bliese and Hanges 2004). MRCM, also referred to as 'hierarchical linear modeling' (Raudenbush and Bryk 2002), has been used to deal with problems arising with clustered data (Cohen et al. 2003; Kenny et al. 2002). In order to justify the use of MRCM, the variance of the dependent variables has to depend on group-related effects (Bliese 1998; 2000). Thus, using the inter-correlation coefficient (ICC) we find that the group variance is .31 for relative-SR variation $\left(\mathrm{ACM}_{\text {relSR }}\right)$ and .14 for absolute-SR variation $\left(\mathrm{ACM}_{\mathrm{absSR}}\right)$. The cumulative measure (ACM) shows an ICC that is .26. In addition to the estimation of variance, we need to define whether this is significantly different from zero. This value is the variance of the intercept term in a model (the null model) that estimates each of the dependent variables based solely on the intercept term with groups used in the random component of the regression equation. In order to understand whether the variance of the intercept is significantly different from zero, we compare this null model with another that does not include groups in its random component and estimation is done via a generalized linear model (i.e., without a random intercept). We compare these two models per each dependent variable using an

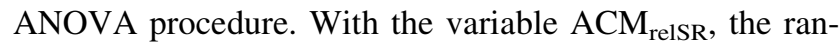
dom intercept model appears significantly different from zero $(\Delta-2$ log-likelihood $=127.444 ; p<.001)$. For the dependent variable $\mathrm{ACM}_{\mathrm{absSR}}$, the random intercept model is also significantly different from zero $(\Delta-2$ log-likelihood $=54.915 ; p<.001)$. The cumulative variable $\mathrm{ACM}_{\mathrm{SR}}$ confirms the trend, showing that the random model is preferred $(\Delta-2 \log$-likelihood $=39.679 ; p<.001)$. The three tests demonstrate that a random intercept provides a better 
estimate than a model without the random component. The equation to estimate the model is of the type

$Y_{i j}=\beta_{0 j}+\beta_{i j} X_{i}+r_{i j}$

with $\beta_{0 j}$ being the intercept that is a function of a fixed intercept and of group-level coefficients, $\beta_{i j}$ is a function of either fixed or random coefficients that depend on the estimate, $X_{i}$ is the set of variables at the individual level, and $r_{i j}$ is the error term. After substituting the terms with the variables of this study, the combined two-level equation is

$$
\begin{aligned}
\mathrm{ACM}_{i j}= & \gamma_{00}+\gamma_{01}(\text { group relative-SR }) \\
& +\gamma_{02}(\text { group absolute-SR })+\gamma_{10}(\text { relative-SR })+ \\
& \gamma_{11}(\text { relative-SR }) *(\text { group relative-SR }) \\
& +\gamma_{20}(\text { absolute-SR })+\gamma_{21}(\text { absolute-SR }) *(\text { group } \\
& \text { absolute-SR })+\gamma_{30}(\text { intellectual openness }) \\
& +\gamma_{40}(\text { group size })+\gamma_{50}(\text { acquaintance })+ \\
& \gamma_{60}(\text { group engagement })+u_{0 j}+u_{1 j}+u_{2 j}+r_{i j}
\end{aligned}
$$

In this MRCM, $u_{0 j}, u_{1 j}$, and $u_{2 j}$ represent the error terms of the random coefficient equations (fixed coefficient equations do not have error terms). Some warnings about endogeneity issues with multilevel modeling have been raised (Leeuw and Meijer 2008) so, we thoroughly tested the mathematical formulation of the model and its results with Hausman's test (1978) and found this problem to be not significant. The same equation is used for $\mathrm{ACM}_{\mathrm{absSR}}$,

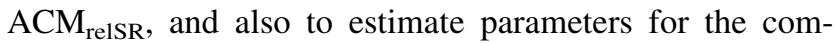
bined effects of group and individual levels on absolute and relative-SR taken together (cumulative $\mathrm{SR}$ or $\mathrm{ACM}_{\mathrm{SR}}$ ). In the procedure, we regress ISR change on initial ISR values, among other variables, consistently with the existing literature on the analysis of change, whether it is individual (e.g., Gino and Moore 2007) or socio-economic (e.g., Barro 1991). Statistical analyses are conducted using $R$ version 3.1.3 (R Core Team 2015), an open source software for statistical analysis.

\section{Results}

\section{Descriptive Statistics}

Table 1 presents descriptive statistics (means, standard deviations, and correlations) for the variables used in the study. As already anticipated in the previous section, there are a few variables showing significant and strong correlations, except for group size and assessed activity $(r=.83)$. Since the two measurements are not used together in the analysis because a combination of these is used instead, this is not an issue in the analysis. As a check for all regression analyses of this study, we performed variance inflation factor (VIF) tests for multicollinearity. Results showed values around 1 for each variable, well below the threshold (Cohen et al. 2003).

\section{Tests of Hypotheses}

H1a postulates that there is a positive correlation between relative-SR and absolute-SR and that the two constructs are different. This issue has been discussed above, when assessing discriminant validity for absolute-SR. Table 1 shows that the two measures are correlated both in the pre(.17) and in the post-group activities (.11). A $t$ test for the difference of means shows that the null hypothesis is rejected $(t=-20.44[d f=919], p<.001$; these are results obtained for measures in the pre-group activities; postgroup results are very similar and not reported here). The two measures are different; H1a is therefore supported.

Under H1b, we compare relative-SR and absolute-SR variability after individuals are exposed to group activities. We hypothesize that relative (case-related) attitudes are more subject to change than the attitudes governed by abstract and general constructs. This is tested using the two measures $\mathrm{WOGA}_{r e l}$ and $\mathrm{WOGA}_{a b s}$ that are instrument tools which assess the weight of group activities over the change of opinions. Another $t$ test provides us with enough information $(t=-1[d f=460], p=.32)$ necessary to conclude that $\mathrm{H} 1 \mathrm{~b}$ is rejected. There is no significant difference concerning how group activity influences individual attitudes toward both relative-SR and absolute-SR. As shown below, this result does not mean that there is no group effect on ISR change or that the result is irrelevant. All that the rejection of H1b tells us is that the ways in which absolute-SR and relative-SR change does not seem to differ.

$\mathrm{H} 2$ assumes that there is a positive relation between ethical judgement on business, and both constructs of relative-SR and absolute-SR. Repeated measures-i.e., preand post-group activities - are highly correlated, as expected (Table 1). We know from the section above that these two SR constructs are different, although business ethics more strongly correlates with relative-SR (.54) than with absolute-SR (-.01), suggesting we probably found a way to distinguish SR from ethics more neatly at the individual level of analysis. Table 2 presents results of an OLS regression that tests the extent to which business ethics affects SR. We tested the hypothesis using a combination of absolute-SR and relative-SR as dependent variables, and then observing the impact on each $\mathrm{SR}$ individually. Model 1, Model 3, and Model 5 (Table 2) present control variables, including the personality trait openness to experience. From Model 2 we observe that the variable business ethics predicts higher SR $(\beta=.44)$ with significantly more variance explained $\left(\Delta \mathrm{R}^{2}=.13\right)$ than the 
Table 1 Descriptive statistics: Means, standard deviations, and Pearson's correlation coefficients

\begin{tabular}{|c|c|c|c|c|c|c|c|c|c|}
\hline Variable & 1 & 2 & 3 & 4 & 5 & 6 & 7 & 8 & 9 \\
\hline \multicolumn{10}{|l|}{1 Age } \\
\hline 2 Gender & 0.01 & & & & & & & & \\
\hline 3 Group size & $-0.13 * *$ & $-0.09 *$ & & & & & & & \\
\hline 4 Existing CSR knowledge & $-0.11 *$ & 0.02 & $0.11^{*}$ & & & & & & \\
\hline 5 Intellectual openness & 0.07 & -0.04 & -0.04 & $0.25 * * *$ & & & & & \\
\hline 6 Bus. ethics attitudes & $-0.08^{\dagger}$ & $-0.15^{* *}$ & 0.06 & 0.02 & -0.03 & & & & \\
\hline 7 Relative-SR & -0.04 & -0.02 & 0.06 & -0.01 & 0.03 & $0.54 * * *$ & & & \\
\hline 8 Absolute-SR & -0.04 & $0.17 * * *$ & -0.04 & -0.04 & $0.11 *$ & -0.01 & $0.17 * * *$ & & \\
\hline 9 Bus. ethics attitudes AG & -0.07 & $-0.08^{\dagger}$ & $0.11 *$ & -0.01 & 0.04 & $0.36^{* * *}$ & $0.22 * * *$ & -0.02 & \\
\hline 10 Relative-SR AG & $-0.08^{\dagger}$ & -0.04 & $0.08^{\dagger}$ & -0.04 & 0.07 & $0.34 * * *$ & $0.47 * * *$ & $0.12 *$ & $0.49 * * *$ \\
\hline 11 Absolute-SR AG & -0.03 & $0.21 * * *$ & $-0.15^{* * *}$ & -0.06 & $0.09 *$ & $-0.09^{*}$ & -0.01 & $0.52 * * *$ & -0.02 \\
\hline 12 Strength of relations & $-0.13 * *$ & -0.03 & 0.07 & 0.08 & 0.05 & 0.02 & -0.05 & 0.13 & -0.03 \\
\hline 13 Length of discussion & $0.09^{\dagger}$ & -0.03 & -0.07 & -0.00 & $0.11^{*}$ & 0.07 & $0.08^{\dagger}$ & -0.01 & -0.01 \\
\hline 14 Group engagement & -0.03 & 0.08 & -0.06 & -0.02 & $0.18 * * *$ & $-0.08^{\dagger}$ & 0.01 & $0.18 * * *$ & 0.03 \\
\hline 15 Assessed activity & -0.05 & -0.05 & $0.83 * * *$ & $0.12 *$ & 0.04 & 0.06 & 0.01 & -0.07 & 0.07 \\
\hline $16 \mathrm{ACM}$-relative-SR & -0.06 & 0.01 & -0.01 & -0.03 & 0.04 & $-0.17 * * *$ & $-0.44 * * *$ & -0.03 & $0.25 * * *$ \\
\hline 17 ACM-absolute-SR & -0.00 & -0.01 & $-0.10^{*}$ & 0.01 & -0.04 & $-0.12 *$ & $-0.22 * * *$ & $-0.60 * * *$ & -0.01 \\
\hline Mean & 22.39 & 0.47 & 4.61 & 0.75 & 4.61 & 3.24 & 4.28 & 5.42 & 3.69 \\
\hline Standard deviation & 2.58 & 0.50 & 0.78 & 0.43 & 0.58 & 1.10 & 0.83 & 0.86 & 1.18 \\
\hline Variable & 10 & 11 & & 12 & 13 & 14 & 15 & 16 & 17 \\
\hline \multicolumn{10}{|l|}{1 Age } \\
\hline \multicolumn{10}{|l|}{2 Gender } \\
\hline \multicolumn{10}{|l|}{3 Group size } \\
\hline \multicolumn{10}{|l|}{4 Existing CSR knowledge } \\
\hline \multicolumn{10}{|l|}{5 Intellectual openness } \\
\hline \multicolumn{10}{|l|}{6 Bus. ethics attitudes } \\
\hline \multicolumn{10}{|l|}{7 Relative-SR } \\
\hline \multicolumn{10}{|l|}{8 Absolute-SR } \\
\hline \multicolumn{10}{|l|}{9 Bus. ethics attitudes $\mathrm{AG}$} \\
\hline \multicolumn{10}{|l|}{10 Relative-SR AG } \\
\hline 11 Absolute-SR AG & $0.11 *$ & & & & & & & & \\
\hline 12 Strength of relations & $0.12 * *$ & -0 & & & & & & & \\
\hline 13 Length of discussion & 0.04 & -0 & & $0.09^{\dagger}$ & & & & & \\
\hline 14 Group engagement & 0.02 & & $22 * * *$ & $0.14 * *$ & $0.14 * *$ & & & & \\
\hline 15 Assessed activity & 0.05 & & $15^{* *}$ & $0.14 * *$ & -0.07 & $-0.09^{\dagger}$ & & & \\
\hline 16 ACM-relative-SR & $0.55^{* * * *}$ & & $14 * *$ & 0.07 & -0.02 & 0.01 & 0.00 & & \\
\hline 17 ACM-absolute-SR & -0.06 & & $31 * * *$ & -0.01 & -0.01 & 0.01 & -0.07 & $0.16^{* * * *}$ & \\
\hline Mean & 4.37 & & 53 & 2.64 & 22.29 & 6.03 & 4.61 & 0.04 & 0.04 \\
\hline Standard deviation & 0.92 & & 78 & 1.12 & 8.98 & 0.74 & 0.76 & 0.23 & 0.21 \\
\hline
\end{tabular}

Note: Strength of relations is calculated as the individual average of the acquaintance level with each member of the group; $A G$ after group activities

Significance codes: $* * * p<.001, * * p<.01, * p<.05,{ }^{\dagger} p<.1$

model with control variables only (Model 1). When we split SR into the two components, we find that only relative-SR is positively affected by business ethics $(\beta=.42)$, and it is also the only significant variable in Models 3 and 4. Models 5 and 6 indicate that absolute-SR is not affected by business ethics $(\beta=.01, p=.70)$, with intellectual 
Table 2 OLS regression results for Business Ethics, Intellectual Openness, and Existing CSR Knowledge on Social Responsibility

\begin{tabular}{|c|c|c|c|c|c|c|}
\hline & $\begin{array}{l}\text { Model } 1 \\
\text { DV: abs+rel SR }\end{array}$ & $\begin{array}{l}\text { Model } 2 \\
\text { DV: abs+rel SR }\end{array}$ & $\begin{array}{l}\text { Model } 3 \\
\text { DV: rel SR }\end{array}$ & $\begin{array}{l}\text { Model } 4 \\
\text { DV: rel SR }\end{array}$ & $\begin{array}{l}\text { Model } 5 \\
\text { DV: abs-SR }\end{array}$ & $\begin{array}{l}\text { Model } 6 \\
\text { DV: abs-SR }\end{array}$ \\
\hline (Intercept) & $\begin{array}{l}9.272 * * * \\
(0.684)\end{array}$ & $\begin{array}{l}7.345 * * * \\
(0.674)\end{array}$ & $\begin{array}{l}4.432 * * * \\
(0.446)\end{array}$ & $\begin{array}{l}2.568 * * * \\
(0.395)\end{array}$ & $\begin{array}{l}4.840 * * * \\
(0.447)\end{array}$ & $\begin{array}{l}4.777 * * * \\
(0.475)\end{array}$ \\
\hline Age & $\begin{array}{l}-0.036 \\
(0.023)\end{array}$ & $\begin{array}{l}-0.021 \\
(0.022)\end{array}$ & $\begin{array}{l}-0.016 \\
(0.015)\end{array}$ & $\begin{array}{l}-0.002 \\
(0.013)\end{array}$ & $\begin{array}{l}-0.020 \\
(0.015)\end{array}$ & $\begin{array}{l}-0.019 \\
(0.015)\end{array}$ \\
\hline Gender & $\begin{array}{l}0.276^{*} \\
(0.119)\end{array}$ & $\begin{array}{l}0.424 * * * \\
(0.112)\end{array}$ & $\begin{array}{l}-0.036 \\
(0.078)\end{array}$ & $\begin{array}{l}0.107 \\
(0.066)\end{array}$ & $\begin{array}{l}0.312 * * * \\
(0.078)\end{array}$ & $\begin{array}{l}0.317 * * * \\
(0.079)\end{array}$ \\
\hline Existing CSR knowledge & $\begin{array}{l}-0.240^{\dagger} \\
(0.145)\end{array}$ & $\begin{array}{l}-0.262^{\dagger} \\
(0.134)\end{array}$ & $\begin{array}{l}-0.056 \\
(0.094)\end{array}$ & $\begin{array}{l}-0.078 \\
(0.079)\end{array}$ & $\begin{array}{l}-0.183^{\dagger} \\
(0.095)\end{array}$ & $\begin{array}{l}-0.184^{\dagger} \\
(0.095)\end{array}$ \\
\hline Intellectual openness & $\begin{array}{l}0.278^{* *} \\
(0.106)\end{array}$ & $\begin{array}{l}0.304 * * \\
(0.099)\end{array}$ & $\begin{array}{l}0.059 \\
(0.069)\end{array}$ & $\begin{array}{l}0.084 \\
(0.058)\end{array}$ & $\begin{array}{l}0.219 * * \\
(0.069)\end{array}$ & $\begin{array}{l}0.220 * * \\
(0.070)\end{array}$ \\
\hline Business ethics attitudes & & $\begin{array}{l}0.438 * * * \\
(0.051)\end{array}$ & & $\begin{array}{l}0.424 * * * \\
(0.030)\end{array}$ & & $\begin{array}{l}0.014 \\
(0.036)\end{array}$ \\
\hline$R^{2}$ & 0.030 & 0.164 & 0.004 & 0.308 & 0.055 & 0.055 \\
\hline$\Delta R^{2}$ & - & 0.134 & - & 0.304 & - & 0.000 \\
\hline$F$-test & 3.478 & 17.883 & 0.508 & 40.444 & 6.647 & 5.340 \\
\hline$p$ value & 0.008 & 0.000 & 0.730 & 0.000 & 0.000 & 0.000 \\
\hline$N$ & 461 & 461 & 461 & 461 & 461 & 461 \\
\hline
\end{tabular}

Significance codes: $* * * p<.001 ; * * p<.01 ; * p<.05 ;{ }^{\dagger} p<.1$

openness $(\beta=.22)$ and gender $(\beta=.32)$ showing positive beta coefficients. $\mathrm{H} 2$ is thus supported, with a strong effect exercised by business ethics on relative-SR.

The remaining hypotheses are tested with MRCM regressions presented in Table 3. Models 1 to 3 in Table 3 indicate no strong relationships between intellectual openness and SR attitude change $\left(\gamma_{30}=-.000\right.$, Model 3), group size, and SR attitude change $\left(\gamma_{40}=-.016\right.$, Model 3), or strength of social relationship among group members $\left(\gamma_{50}=.005\right.$, Model 3). Thus, $\mathrm{H} 3, \mathrm{H} 4$, and $\mathrm{H} 5$ are rejected.

Group engagement is found to be positively associated with absolute-SR $\left(\gamma_{60}=.022\right.$, Model 2$)$, and the cumulative measure of SR change after group activities $\left(\gamma_{60}=.030\right.$, Model 3) although it is unrelated to relative$S R$. The effect on a combined SR change is still positive and significant ( $p<.05$ level) even if one of the two legs of SR change (relative-SR) has a non-significant coefficient. Hence, the overall effect is still strong despite being completely related to the impact of absolute-SR on cumulative ISR change. It is indisputable that an impact of some ISR change is in place and H6 is therefore accepted. $\mathrm{H} 7 \mathrm{a}$ states that individuals with higher appreciation of SR are more likely to stick to their initial opinions. Table 3 shows that both absolute- and relative-SR are negatively related to attitude change measurement (ACM; $\gamma_{10}=-$ $.198 ; \gamma_{20}=-.170$ in Model 3). In other words, the higher the initial set of attitudes toward SR, the more one is likely to change his or her opinion. The negative coefficient indicates a negative slope in the regression line; hence, the higher initial attitudes toward SR, the lower the change. $\mathrm{H} 7 \mathrm{a}$ is thus accepted.

$\mathrm{H} 7 \mathrm{~b}$ suggests that higher levels of group social responsibility positively affect individuals' change of attitudes toward SR. In Model 3 there is a positive and significant impact of the group on ACMSR $\left(\gamma_{01}=.228 ; \gamma_{02}=.190\right)$. The same effects are found in the other two models, with group relative-SR $\left(\gamma_{01}=.222\right)$ and group absolute-SR $\left(\gamma_{02}=.179\right)$ that appear to be significant in Model 1 and Model 2, respectively. There is a positive effect of groups on the individual change of attitudes that suggests $\mathrm{H} 7 \mathrm{~b}$ is accepted. A further consideration of these relationships (Table 3) indicates that there is an impact of how the group affects ISR as it predicts the change of attitudes $\left(\mathrm{ACM}_{r e l}\right.$, $\mathrm{ACM}_{a b s}$, and $\mathrm{ACM}_{S R}$ ). The first finding is that there is a moderation effect, although very small, and group SR variations affects the relationship between the two variables in all three models $\left(\gamma_{11}=-.036\right.$, Model $1 ; \gamma_{11}=-$ $.023, p<.1$, Model 3; and $\gamma_{21}=-.069$, Model $2 ; \gamma_{21}=-$ .085 , Model 3). However, the direction of the coefficients is always negative, meaning that group SR affects those individuals with lower levels of SR and, therefore, provides additional ground for accepting H7b.

To further support these results, Figs. 2 and 3 present interaction plots of two classes of individuals: (a) those 
Table 3 Results of the Multilevel Random Coefficient Model (MRCM) Regressions

\begin{tabular}{|c|c|c|c|}
\hline & $\begin{array}{l}\text { Model } 1 \\
\text { DV: ACM }\end{array}$ & $\begin{array}{l}\text { Model } 2 \\
\text { DV: ACM } \\
a b s\end{array}$ & $\begin{array}{l}\text { Model } 3 \\
\text { DV: } \mathrm{ACM}_{S R}\end{array}$ \\
\hline \multirow[t]{2}{*}{$($ Intercept $) \gamma_{00}$} & 0.043 & -0.071 & -0.027 \\
\hline & $(0.070)$ & $(0.062)$ & $(0.096)$ \\
\hline \multirow[t]{2}{*}{ Relative-SR $\gamma_{10}$} & $-0.175^{* * *}$ & $-0.023 * *$ & $-0.198 * * *$ \\
\hline & $(0.009)$ & $(0.008)$ & $(0.012)$ \\
\hline \multirow[t]{2}{*}{ Absolute-SR $\gamma_{20}$} & 0.009 & $-0.179 * * *$ & $-0.170 * * *$ \\
\hline & $(0.008)$ & $(0.008)$ & 0.012 \\
\hline \multirow[t]{2}{*}{ Group relative-SR $\gamma_{01}$} & $0.222 * * *$ & 0.005 & $0.228 * * *$ \\
\hline & $(0.010)$ & $(0.009)$ & $(0.014)$ \\
\hline \multirow[t]{2}{*}{ Group absolute-SR $\gamma_{02}$} & 0.010 & $0.179 * * *$ & $0.190 * * *$ \\
\hline & $(0.014)$ & $(0.012)$ & $(0.019)$ \\
\hline \multirow[t]{2}{*}{ Intellectual openness $\gamma_{30}$} & -0.008 & -0.008 & -0.000 \\
\hline & $(0.011)$ & $(0.010)$ & $(0.015)$ \\
\hline \multirow[t]{2}{*}{ Group size $\gamma_{40}$} & -0.008 & -0.007 & -0.016 \\
\hline & $(0.009)$ & $(0.008)$ & $(0.012)$ \\
\hline \multirow[t]{2}{*}{ Strength of relations $\gamma_{50}$} & 0.003 & 0.002 & 0.005 \\
\hline & $(0.006)$ & $(0.005)$ & $(0.008)$ \\
\hline \multirow[t]{2}{*}{ Group engagement $\gamma_{60}$} & 0.007 & $0.022 * *$ & $0.030 *$ \\
\hline & $(0.009)$ & $(0.008)$ & $(0.013)$ \\
\hline \multirow[t]{2}{*}{ Relative-SR $\times$ Group rel SR $\gamma_{11}$} & $-0.036 * * *$ & 0.013 & $-0.023^{\dagger}$ \\
\hline & $(0.010)$ & $(0.009)$ & $(0.014)$ \\
\hline \multirow[t]{2}{*}{ Absolute-SR $\times$ Group abs-SR $\gamma_{21}$} & -0.016 & $-0.069 * * *$ & $-0.085 * * *$ \\
\hline & $(0.014)$ & $(0.013)$ & $(0.020)$ \\
\hline
\end{tabular}

Significance codes: $* * * p<.001 ; * * p<.01 ; * p<.05 ;{ }^{\dagger} p<.1$ with low initial social responsibility (dotted red line), and (b) those with high initial social responsibility (solid blue line). The two figures show individual relative-SR and absolute-SR, respectively. The two classes are plotted against low and high social responsibility of their respective groups, and attitude toward change (ACM). What emerges from the two plots is that individuals with below- mean SR show the highest change when the group-level SR goes from low to high, while people who already have above-mean SR do not change much. This strengthens our findings for $\mathrm{H} 7 \mathrm{a}$ and $\mathrm{H} 7 \mathrm{~b}$.

Table 4 summarizes all the hypotheses and their results. We explain our findings in the discussion part below.
Fig. 2 Interaction plot of the effect of group relative-SR on the relationship between the individual relative-SR and attitude change mechanism (ACM)

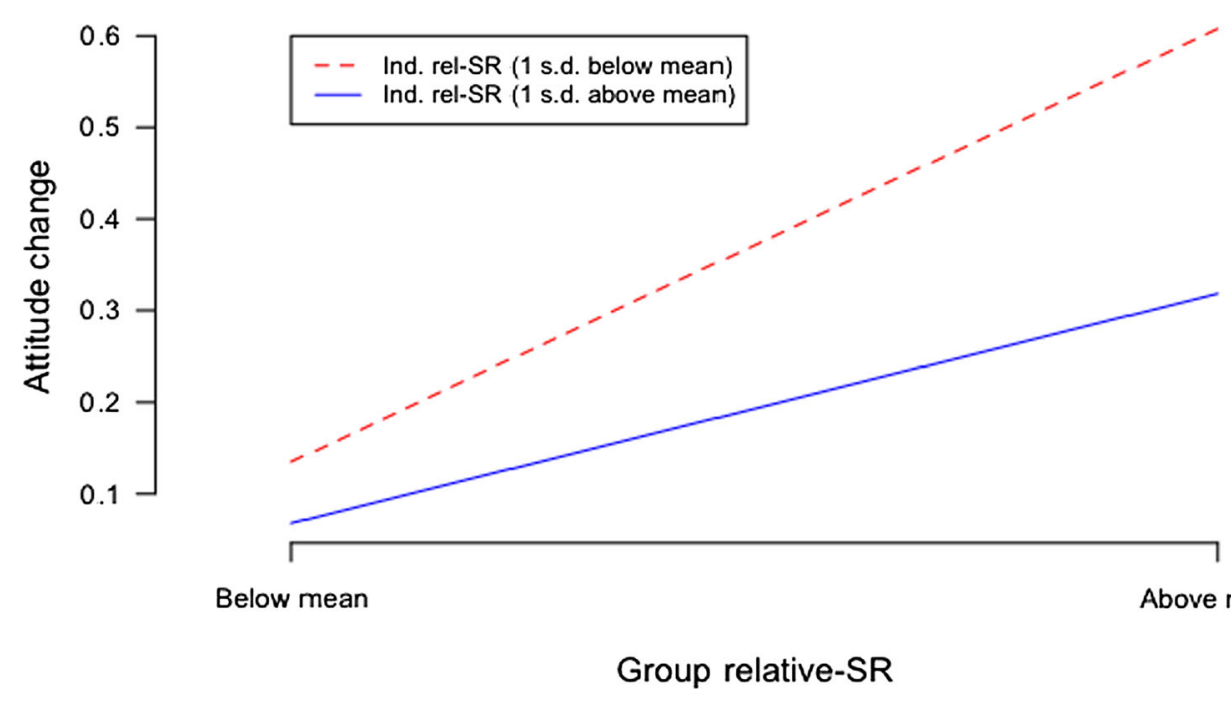


Fig. 3 Interaction Plot of the effect of group absolute-SR on the relationship between the individual absolute-SR and attitude change mechanism (ACM)

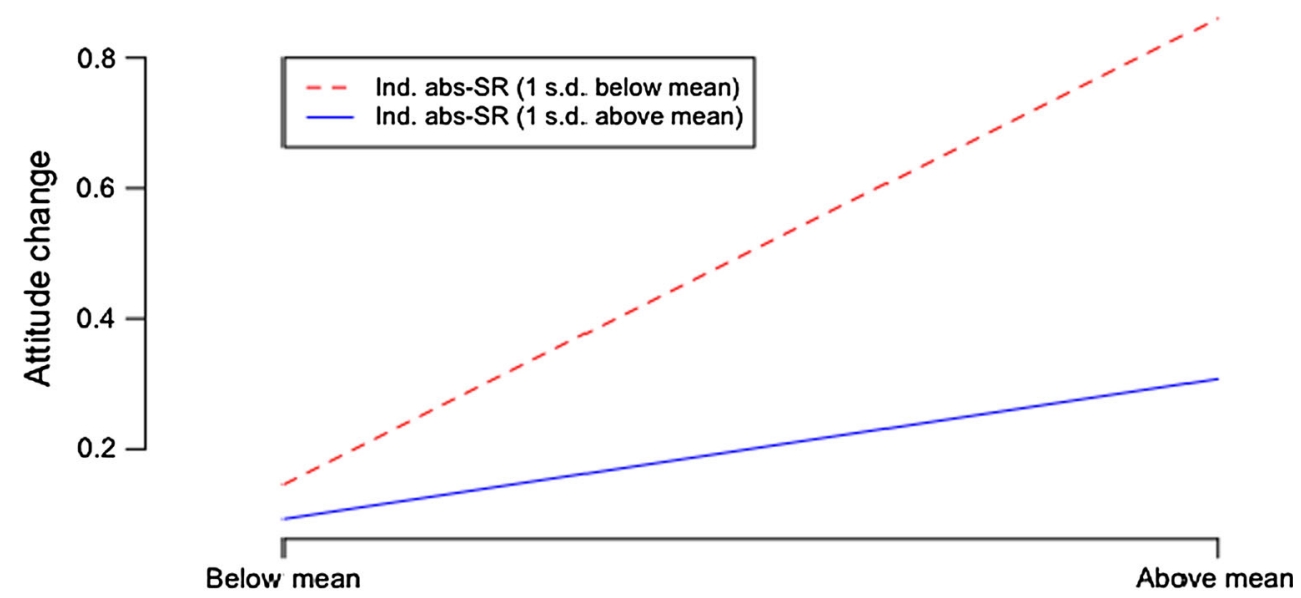

Group absolute-SR

Table 4 Summarizing the outcomes of the hypotheses

\begin{tabular}{ll}
\hline Hypotheses & Results \\
\hline H1a: There is a more practical attitude toward SR, or relative-SR, which is correlated with but & Supported \\
different from a more abstract SR attitude, or absolute-SR & Rejected (The way the two change does \\
H1b: Attitudes toward relative-SR are more likely to change under the effects of group activities as to differ) \\
opposed to absolute-SR attitudes & $\begin{array}{c}\text { Supported } \\
\text { H2: Individual attitudes toward business ethics affect one's attitudes toward SR }\end{array}$ \\
H3: Intellectual openness positively affects individual SR attitudes & Rejected \\
H4: The larger the group size, the less likely it is for individuals to change their attitudes toward SR & Rejected \\
H5: The strength of social relationship among group members positively affects the change of ISR & Rejected \\
attitudes & \\
H6: Higher group engagement increases the likelihood that individual attitudes toward SR change as & Supported \\
an effect of group activities & Supported \\
H7a: Individuals that highly value SR are more likely to stick to their initial opinion & Supported \\
H7b: Higher levels of group SR positively affect individual changes of attitudes toward SR &
\end{tabular}

\section{Discussion}

Acting as a 'gap-spotter' (Alvesson and Sandberg 2013), this study has addressed two existing issues in the literature. The first issue is that ethics and SR are usually considered (and measured) together with no clear distinctions being made between the two (Maignan 2001; Salmones et al. 2005; Singhapakdi et al. 1996). The second issue is that the literature has neglected socialization effects of the group on individual attitudes toward SR (Aguinis and Glavas 2012; Windsor 2001).

Acting as a 'path-setter' (Alvesson and Sandberg 2013) and theory builder (Colquitt and Zapata-Phelan 2007), this study provides some support for the fact that SR can be defined as absolute, which is a general, abstract tendency or idealistic view of business-society relations, and relative, an issue-based, specific view of SR, as it relates to a given problem, business, or case at hand. Furthermore, it presents a model to understand how these two layers of SR interact with group dynamics. This model has several key theoretical and managerial implications.

\section{Theoretical Implications}

First, individual SR is not static. It changes via the socialization processes of group dynamics. In other words, when individuals interact with each other, their SR perception is likely to change. This finding suggests that SR should be addressed more from the social cognition perspective, as already suggested in a previous study (Secchi 2009) rather than from the more traditional approach that considers the individual in isolation (Aguinis and Glavas 2013).

Second, this study contributes to theory building (Colquitt and Zapata-Phelan 2007) by defining two layers of SR, and demonstrating how they change as a result of group interactions. The findings indicate that individual SR 
has two faces: one relative (specific to a given case or issue at hand), and one absolute (general propensity to view the nature of the relation between business and society universally). These two 'faces' are captured by relative-SR and absolute-SR; the two constructs affect and are affected by group activities differently. Thus, our findings suggest that individual perception of SR is multi-faceted. Most of the existing approaches and tools seem to lean toward the relative-SR, whereas we show that the phenomenon needs to be addressed more holistically. Groups are much diffused in everyday work life and many decisions are made through interactions (Levine and Moreland 1990). The point that emerges from our study, that first addresses the relative/absolute dimensions of SR for the first time, is that this distinction between the two SR should be taken into consideration

Third, both absolute-SR and relative-SR impact attitudinal change (ACM) negatively. These are individual-level measures that change as a result of individual and group interactions. The attitudinal change assumes positive and negative values, depending on the direction of the change. For example, the negative coefficient suggests that the higher the initial SR, the lower the likelihood that it will change. This can be regarded as a compensation effect. Our findings show that the higher the group attitudes toward relative-SR or absolute-SR, the higher the impact on individual attitude change. On the one hand, participants with high SR are less likely to change. On the other hand, their high SR significantly affects other members of the group. From this result, a recommendation to organizations that work on the implementation of CSR is to build groups while keeping in mind what the average starting level of individual SR is among group members. One or more individuals scoring high (particularly in relative-SR, if we judge based on regression coefficients) is likely to affect the change of attitudes of the other group members.

Finally, the above points direct us to the role of groups in the shaping of SR thinking and, eventually, behavior (Ajzen 2005). As far as change of opinions is concerned, there are two concepts that can be considered. A group provides a good environment for people to consider or discount the opinions of others (Bonaccio and Dalal 2006; Moreland and Levine 2002). This study demonstrates that, contrary to previous findings in group research (Levine and Moreland 1990), the strength of social relationships (acquaintance), group size and, surprisingly, intellectual openness, may not be relevant for people to shape their ideas on SR. Instead, engagement in group activities seems to play a more significant role. A fundamental point here is that the more people feel engaged in and actively part of a group, the more their SR thinking is likely to change and adapt.

A group serves as a sort of cognitive mediator for its individual members (Magnani 2007). When individuals shape their cognition while doing (or, in our case, discussing) something, they are performing what Magnani (2009, p. 46) defines manipulative abduction (i.e., the idea of 'thinking through doing'). The group is somehow 'manipulated' by individual members and facilitates cognitive processes that lead those individuals with higher SR to change and adapt more easily. In other words, this case could well serve as an example of how ISR works as socially distributed cognition (Alač and Hutchins 2004). In short, this opens an interesting subject for future research.

\section{Practical Implications}

This study suggests practical implications in three areas of relevance-i.e., the nature of working relations, organizational structures, and training practices. Firstly, the literature on advice giving and taking suggests that expert advice has more chances to go through and be used by the decision maker (Sniezek et al. 2004). This could be a variable to take into consideration, although there is not enough information to derive this implication from the data presented here. The only information the data allow us to infer is that higher levels of ISR have a clear impact on groups and this may not necessarily mean expertise but it can be considered somehow similar to that.

On a different tack, findings highlight that there is no influence concerning the strength of relations among group members over the final change of attitude (ACM). This is particularly interesting when it comes to team building, contrary to what previous literature (e.g., Moreland et al. 1996) suggests.

The second practical implication concerns the impact of group work. Our research suggests that groups are a useful and effective means for conveying SR issues. Group work (slightly) moderates information on SR, so that organizations should think more seriously about group activities when implementing, discussing, and disseminating SR information to their employees. This is a particularly simple implication that may take the form of advice to managers: use groups more often. Although it is not clear what direction the group activities and individual attitudes will take, results show that change occurs through group dynamics. The time lag that we used for this study was minimal (1 week), but participants still showed significant change in both their relative and absolute attitudes toward SR.

Finally, this study was conducted among final year business students, who had at least one year of company work experience (the average is 3.25 years). These people represent the next generation of business managers, possibly with new perceptions and beliefs of SR in the current work environment. Therefore, what they think and perceive can be regarded as a marker for their future decisions as 
managers. Consistent with recent literature on samples (Shen et al. 2011), we argue that the use of these young people in this study is supported by the fact that we were exploring whether a phenomenon existed.

\section{Limitations}

Although the study is 'path-setting' and was thoughtfully designed, there still remain some limitations that need to be solved in future research when the literature is more developed. The first concern relates to measures. We utilized those measures that seemed to be the most appropriate and relevant for our study. However, this is still an area where there is less research compared to that so far conducted on the organizational or corporate SR level of analysis. To ensure the appropriateness of the measures (reliability and validity), we ran several tests although further tests and analyses on other measures-for example, the multidimensional scale for ethical decision making (Casali 2011), the global social responsibility scale (Starrett 1996), or some other constructs from the so-called big five (Costa and McCrae 1992) - may offer additional ground to support (or reject) our hypotheses. Also, there may be more accurate measures to assess inter-personal relationships among group members.

Second, when we planned the quasi-experiment, we did not set the same group size for everyone. This might have allowed us to obtain more robust results, hence it may account for one of the limitations of this study. Moreover, there was no control group in the experiment (i.e., the control we used was size variation). This would have been particularly difficult since we could not justify excluding students from group work. This might be counted as another limitation. Future research will have venue for field study which might provide more factual findings than a quasi-experiment.

Finally, generalization of results may be hampered by the fact that the majority of participants came from the UK $(87 \%)$, though the sample size is a good fit for our analytical purposes (i.e., $N=461$, statistical power is approximately .90). People from different cultures or from countries with different levels of economic development might perceive SR differently. Therefore, findings of this study should be interpreted with caution.

\section{Conclusion}

This paper presented a study on how individuals change their attitudes toward SR as a result of group activities. We have isolated antecedents of ISR (i.e., business ethics and intellectual openness) and related them to group size, engagement, and strength of social relationships among members. The study shows that individuals have a different understanding of SR when they deal with a practical issue (relative-SR) as opposed to when they think of abstract business-society relations (absolute-SR). These two attitudes toward SR affect the way a group acts on individuals. Both relative-SR and absolute-SR negatively affect attitudinal change of opinion while the effect of the group engagement affects it positively. This opens venues for further theory development concerning how these two attitudes might affect organizational citizenship behavior, or decision making among business managers, for example.

The paper also suggests that SR is distinct from ethics, yet dependent on it; it is affected by, and significantly affects, group dynamics. Future studies should consider how individuals are facilitated in their attitudinal change when implementing, discussing, addressing, or assessing SR. This will stimulate scholars to reconsider and develop more theories on the interactions between individual and corporate social responsibility, the group being probably one of the many meso-levels of enquiry.

Open Access This article is distributed under the terms of the Creative Commons Attribution 4.0 International License (http://crea tivecommons.org/licenses/by/4.0/), which permits unrestricted use, distribution, and reproduction in any medium, provided you give appropriate credit to the original author(s) and the source, provide a link to the Creative Commons license, and indicate if changes were made.

\section{Appendix 1}

\section{Case: $\operatorname{ReNu}^{\circledR}$. Too Much Cleansing!}

Do you use contact lenses? Do you use them often? If your answer is 'yes' then there is a very good possibility that you know $\mathrm{ReNu}^{\circledR}$, a solution for cleaning, disinfecting, and storing your contact lenses by Bausch and Lomb (B\&L).

\section{Bausch \& Lomb: The Company}

Founded in 1853, the company has its headquarter in Rochester (NY). It employs about 13,000 people and sells its products in more than 100 countries worldwide. The areas of operation are (a) contact lenses and related products, (b) pharmaceuticals, as well as (c) cataract and eye surgery. ${ }^{1}$

The company's total sales for the year of 2005 were $\$ 2354$ million, profits registered at $\$ 19.2$ million; the revenue growth rate in the years 2003-2005 averaged $7.0 \%$. Their Research and Development $(\mathrm{R} \& \mathrm{D})$ expenses totaled

\footnotetext{
$\overline{1}$ Information retrieved online at http://www.bausch.com/en_US/ corporate/ir/general/profile.aspx, October 17, 2015 11:17 AM.
} 
$\$ 177.5$ million (7.5\% of revenues), and the operating income was stable at $12 \%$ in 2005. The lens care segment of their business counts for about $18 \%$ of their revenues. ${ }^{2}$ Their stocks are traded in the New York Stock Exchange.

In their 39-page Code of Business Conduct and Ethics, B\&L state their purpose is to "stay true to a vision." With a one-word/multiple-meaning statement, the vision is that of the founders: to improve the way people see. The Code states that the company "must maintain an ethical culture," and they implement it with a commitment to ethical principles and with rules for sound decision making. ${ }^{3}$

\section{ReNu ${ }^{\circledR}$ with MoistureLoc}

The solution, one of the company's blockbuster products serves many purposes at the same time: it (a) cleans contact lenses and (b) removes proteins and other deposits that remain after use. The product accounted for $\$ 45$ million of sales in $2004 .^{4}$ The family of $\mathrm{ReNu}^{\circledR}$ products are sold worldwide to an estimated 20 million customers. ${ }^{5}$

\section{Some Troubling Results}

It was February 20th, 2006 when the Health Ministry of Singapore issued a press release stating that out of 18 cases of serious eye infection, $100 \%$ used B\&L's multi-purpose solution. ${ }^{6}$ The following day, the Health Ministry suggested that contact lens users stop using B\&L's $\mathrm{ReNu}^{\circledR}$ "because of a 'very strong association' between the solution and a recent spate of fungal corneal infections." number of people affected at that time in Singapore was 39, of which 34 said they used the solution. According to the Malaysian New Straits Times ${ }^{8}$ similar cases were found in Hong Kong. Far from being isolated to the Asian market, similar cases were found in the United States. The eye infection was found in 109 contact lens users over a

\footnotetext{
${ }^{2}$ Bausch \& Lomb 2011. Historical GAAP Statements of Income. Retrieved online at http://www.bausch.com/en_US/downloads/corpo rate/ir/general/RESTATED_financials.pdf, October 15, 2015 11:17 AM. See also Feder, B. J. 2006. Lens Cleaner Is Recalled Worldwide. New York Times, May 16, Section C, p. 1.

${ }^{3}$ Bausch \& Lomb 2008. Stay True to a Vision. Code of Business Conduct and Ethics. Rochester, NY: B\&L.

${ }^{4}$ IHT, 2006. Bausch chief backs safety of its ReNu lens cleaner. International Herald Tribune, April 13.

${ }^{5}$ Information retrieved online at http://www.bausch.co.za/Consumer/ ContactLensesCare/SoftLensCare/tabid/103/Default.aspx?PageContent Mode=1, October 17, 2015 11:17 AM.

${ }^{6}$ Khalik, S. 2006. Spike in cases of blinding eye infection has experts baffled. The Straits Times, February 21, 2006.

${ }^{7}$ Khalik, S. 2006. Stop using Bausch \& Lomb lens solution, $\mathrm{MOH}$ advises. The Straits Times, February 22, 2006.

${ }^{8}$ Bausch \& Lomb will not offer refunds, New Strait Times, March 17, 2006.
}

10-month period ending April 2006. The U.S. Centers for Disease Control and Prevention reported that the infection was fusarium keratitis, a corneal infection that, in some cases, may result in serious corneal injuries and blindness if a transplant is not performed. ${ }^{9}$

The Food and Drug Administration (FDA) decided to inspect B\&L's manufacturing facility, located in Greensville, S.C. ${ }^{10}$ The inspection was supposed to determine the fate of the case.

According to Ron Zarrella, the company's CEO, the solution was safe. On April 12, he claimed, "tests had shown the lens cleanser ReNu with MoistureLoc was effective in killing the fusarium keratitis fungus that causes the infection on the cornea." Moreover, he also stated that $\mathrm{ReNu}^{\circledR}$ is "as safe and effective as anything on the market" and that "there's no indication there is a formula problem here." 11

Market analysts warned of dangers "that there is permanent damage to the brand" 12 and the share price started plummeting as soon as the news of the infection was released in the U.S. ${ }^{13}$ In the meantime, major drugstore chains in the U.S., including CVS, Walgreens, and JewelOsco, started to wonder whether to take actions to protect their customers instead of awaiting the company's decision.

\section{Open-Ended Questions (Not Used in the Analyses)}

1. What are the alternatives that the company faces? And what are the consequences related to each alternative? Try to answer as if you were a manager of the company.

2. How many dimensions/types of social responsibility can be related to the case?

3. On the basis of your answer to question 2, what is the strategy that you think managers should embrace to effectively deal with the situation?

\section{Appendix 2}

With the aim of contributing to the diffusion of research in individual and group social responsibility, Appendix 2 includes all the measurement variables used in this study. The two key variables (absolute and relative SR) are presented with a higher degree of detail.

\footnotetext{
9 Biotech Business Week, January 29, 2007, Medical study results announced by Centers for Disease Control and Prevention, U.S., p. 1817.

10 Walsh, J. \& Moore, D. 2006. Firm will not recall lens cleaner. Philadelphia Inquirer, April 13, p. C01.

11 IHT, 2006 ibid.

12 Walsh, J. \& Moore, D. 2006. Ibid.

${ }^{13}$ Walsh, J. \& Moore, D. 2006. Ibid.
} 


\section{Ethical Judgement}

[7-point bipolar scale]

\begin{tabular}{|c|c|c|c|c|c|c|c|c|}
\hline Unfair & 1 & 2 & 3 & 4 & 5 & 6 & 7 & Fair \\
\hline Unjust & 1 & 2 & 3 & 4 & 5 & 6 & 7 & Just \\
\hline $\begin{array}{l}\text { Unacceptable to } \\
\text { my family }\end{array}$ & 1 & 2 & 3 & 4 & 5 & 6 & 7 & $\begin{array}{l}\text { Acceptable to my } \\
\text { family }\end{array}$ \\
\hline Not morally right & 1 & 2 & 3 & 4 & 5 & 6 & 7 & Morally right \\
\hline $\begin{array}{l}\text { Culturally } \\
\text { unacceptable }\end{array}$ & 1 & 2 & 3 & 4 & 5 & 6 & 7 & $\begin{array}{l}\text { Culturally } \\
\text { acceptable }\end{array}$ \\
\hline $\begin{array}{l}\text { Traditionally } \\
\text { unacceptable }\end{array}$ & 1 & 2 & 3 & 4 & 5 & 6 & 7 & $\begin{array}{c}\text { Traditionally } \\
\text { acceptable }\end{array}$ \\
\hline $\begin{array}{l}\text { Violate unspoken } \\
\text { promise }\end{array}$ & 1 & 2 & 3 & 4 & 5 & 6 & 7 & $\begin{array}{l}\text { Not violate } \\
\text { unspoken } \\
\text { promise }\end{array}$ \\
\hline $\begin{array}{l}\text { Violate unwritten } \\
\text { contract }\end{array}$ & 1 & 2 & 3 & 4 & 5 & 6 & 7 & $\begin{array}{c}\text { Not violate } \\
\text { unwritten } \\
\text { contract }\end{array}$ \\
\hline
\end{tabular}

Adapted from Reidenbach and Robin (1990)

\section{Relative-SR}

[1 = strongly disagree; $7=$ strongly agree $]$

The measure for relative social responsibility was revised from Garcia de los Salmones et al. (2005). We adjusted the items to fit the case presented to participants but the measure is very much the same as the original:

State whether you disagree or agree with the following statements about the company $(B \& L)$

1. tries to obtain maximum profit from its activities

2. tries to obtain maximum long-term success

3. always tries to improve its economic performance

4. always respects the norms defined in the law when carrying out its activities

5. is concerned to fulfill its obligations vis-a'-vis its shareholders, suppliers, distributors, and other agents with whom it deals

6. behaves ethically/honestly with its customers

7. respects ethical principles in its relationships

8. is concerned to respect and protect the natural environment

9. is concerned to improve the general well-being of society

\section{Absolute-SR \\ $[1=$ non-existent/irrelevant; $\quad 7=$ core $\quad$ value/totally relevant]}

The measure for absolute social responsibility was developed following a two-step procedure. First, we listed 28 expressions that we thought could represent what a socially responsible business should do. Second, we submitted the list to colleagues with expertise in the field of either ethics, social responsibility, and scale development (DeVellis 2012) and asked to assess whether these expressions represented $a b$ solute-SR (spelling out its meaning). After a few rounds we then retained 12 items. Third, we pilot tested the measure with a small random sample of participants and ran preliminary EFA and CFA. We repeated these tests for measure validation and performed an EFA with participants of the first wave $(n=276)$; results are the following:

$\begin{array}{ll}\text { 1. Proactive business strategy } & 0.636 \\ \text { 2. Corporate values } & 0.752 \\ \text { 3. Employees rights } & 0.743 \\ \text { 4. Economic performance } & 0.505 \\ \text { 5. Societal care } & 0.708 \\ \text { 6. Philanthropy } & 0.632 \\ \text { 7. Diversity promotion } & 0.636 \\ \text { 8. Law-abiding behavior } & 0.756 \\ \text { 9. Ecological responsibility } & 0.683 \\ \text { 10. Product quality } & 0.706 \\ \text { 11. Risk seeking } & 0.300 \\ \text { 12. Human rights } & 0.778 \\ \text { Total variance explained } & 0.443\end{array}$

Item 11 loads poorly on the scale compared to the others $(<0.40)$. A subsequent CFA performed with the data from the post-test for participants of both waves confirms that a measure with 12 items loads well on one factor: $\chi^{2}=112.511$ $[d f=35], p<.001 ; \chi^{2} / d f=3.215 ;$ CFI $=.966$; RMSEA $=$ $.069 ;$ SRMR $=.041 ; \mathrm{BIC}=15883.809$, although the $\chi^{2} / d f$ is not within the recommended range. If we consider a 11-item measure, results are slightly better: $\chi^{2}=73.085[d f=27]$, $p<.001 ; \quad \chi^{2} / d f=2.706 ; \quad$ CFI $=.979 ; \quad$ RMSEA $=.060 ;$ SRMR $=.036 ;$ BIC $=14376.349$. The difference between the aggregated 11-item and 12-item scale was not statistically significant; hence, we kept the 12-item scale leaving more finegrained discussions of validity/reliability to a measurement paper. The test we performed and reported in the paper are conducted with the larger sample, this is why some of the indices report slightly different (still consistent) values. The scale construction procedure we followed together with these preliminary tests indicates some support for the validity of the proposed scale. Full validation and reliability analysis will be published in a separate paper, including a discussion on whether this scale can be considered a reflective (as we did here) or a 
formative scale. The way values are aggregated do not pose threats to the measure in the analysis of this paper.

As a final step in our process, we included the scale in the quasi-experiment. Here are items and wording that we used for the scale of absolute-SR.

Describe what you think for each of the following words and expressions as core values of operating businesses. Use numbers from 1 to 7, where 1 is "non-existent/irrelevant" and 7 is "core value/totally relevant."

\begin{tabular}{llllllll}
\hline $\begin{array}{l}\text { Proactive business } \\
\quad 1 \text { strategy }\end{array}$ & 1 & 2 & 3 & 4 & 5 & 6 & 7 \\
Corporate values & 1 & 2 & 3 & 4 & 5 & 6 & 7 \\
Employees rights & 1 & 2 & 3 & 4 & 5 & 6 & 7 \\
Economic performance & 1 & 2 & 3 & 4 & 5 & 6 & 7 \\
Societal care & 1 & 2 & 3 & 4 & 5 & 6 & 7 \\
Philanthropy & 1 & 2 & 3 & 4 & 5 & 6 & 7 \\
Diversity promotion & 1 & 2 & 3 & 4 & 5 & 6 & 7 \\
Law-abiding behavior & 1 & 2 & 3 & 4 & 5 & 6 & 7 \\
Ecological & 1 & 2 & 3 & 4 & 5 & 6 & 7 \\
$\quad$ responsibility & 1 & 2 & 3 & 4 & 5 & 6 & 7 \\
Product quality & 1 & 2 & 3 & 4 & 5 & 6 & 7 \\
$\quad$ Risk seeking & 1 & 2 & 3 & 4 & 5 & 6 & 7 \\
Human rights & & & & & &
\end{tabular}

\section{Intellectual Openness}

$[1=$ strongly disagree $7=$ strongly agree $]$

1. I carry the conversation to a higher level

2. I prefer to stick with things that I know

3. I am interested in many things

4. I prefer variety to routine

5. I am not interested in abstract ideas

6. I am not interested in theoretical discussions

7. I want to increase my knowledge

8. I rarely look for a deeper meaning in things

9. I am open to change

10. I try to avoid complex people.

From Jackson et al. (2000)

\section{Group Engagement}

[1 = strongly disagree; $7=$ strongly agree $]$

During the discussion I believe that...

1. I felt comfortable expressing my opinions
2. I have always been keen on accepting opinions from other members of the group

3. Overall, the opinion of the group was very similar to what I was thinking before.

\section{References}

Aguilera, R. V., Rupp, D. E., Williams, C. A., \& Ganapathi, J. (2007). Putting the s back in corporate social responsibility: A multilevel theory of social change in organizations. Academy of Management Review, 32(3), 836-863.

Aguinis, H., \& Glavas, A. (2012). What we know and don't know about corporate social responsibility: A review and research agenda. Journal of Management, 38, 932-968.

Ajzen, I. (2005). Attitudes, personality, and behavior. New York: Open University Press.

Alač, M., \& Hutchins, E. (2004). I see what you are saying: action as cognition in fMRI brain mapping practice. Journal of Cognition and Culture, 4, 629-661.

Alvesson, M., \& Sandberg, J. (2011). Generating research questions through problematization. Academy of Management Review, 36, 247-271.

Alvesson, M., \& Sandberg, J. (2013). Has management studies lost its way? Ideas for more imaginative and innovative research. Journal of Management Studies, 50, 128-152.

Angelidis, J., \& Ibrahim, N. (2004). An exploratory study on the impact of degree of religiousness upon an individual's corporate social responsiveness orientation. Journal of Business Studies, 51(2), 119-128.

Bardone, E. (2011). Seeking chances. From biased rationality to distributed cognition. New York: Springer.

Barkemeyer, R. (2009). 'Beyond compliance-below expectations? CSR in the context of international development. Business Ethics, 18, 273-289.

Bauman, C. W., \& Skitka, L. J. (2012). Corporate social responsibility as a source of employee satisfaction. Research in Organizational Behavior, 32, 63-86.

Berkowitz, L., \& Connor, W. H. (1966). Success, failure, and social responsibility. Journal of Personality and Social Psychology, 4(6), 664-669.

Berkowitz, L., \& Daniels, L. R. (1964). Affecting the salience of the social responsibility norm. Journal of Abnormal and Social Psychology, 68, 275-281.

Berkowitz, L., \& Lutterman, K. G. (1968). The traditional socially responsible person. Public Opinion Quarterly, 32, 169-185.

Bettenhausen, K. L. (1991). Five years of group research: What we have learned and what needs to be addressed. Journal of Management, 17, 345-381.

Bliese, P. D. (1998). Group size ICC values, and group-level correlations: A simulation. Organizational Research Methods, 1, 355-373.

Bliese, P. D. (2000). Within-group agreement, non-independence, and reliability: Implications for data aggregation and analysis. In K. J. Klein \& S. W. Kozlowski (Eds.), Multilevel theory, research, and methods in organizations (pp. 349-381). San Francisco, CA: Jossey-Bass Inc.

Bliese, P. D., \& Hanges, P. J. (2004). Being both too liberal and too conservative: the perils of treating grouped data as though they were independent. Organizational Research Methods, 7, 400-417.

Bonaccio, S., \& Dalal, R. S. (2006). Advice taking and decisionmaking: An integrative literature review, and implications for 
the organizational sciences. Organizational Behavior and Human Decision Processes, 101, 127-151.

Bondy, K., \& Starkey, K. (2012). The dilemmas of internationalization: Corporate social responsibility in the multinational corporation. British Journal of Management, 25, 4-22.

Bowie, N. (1991). New directions in corporate social responsibility. Business Horizons, 34(4), 56-66.

Cannon-Bowers, J. A., \& Salas, E. (2001). Reflections on shared cognition. Journal of Organizational Behavior, 22, 195-202.

Cappel, J. J., \& Windsor, J. C. (2000). Ethical decision making: a comparison of computer-supported and face-to-face group. Journal of Business Ethics, 28, 95-107.

Carmeli, A., Gilat, G., \& Waldman, D. A. (2007). The role of perceived organizational performance in organizational identification, adjustment and job performance. Journal of Management Studies, 44, 972-992.

Carroll, A. B. (1979). A three dimensional conceptual model of corporate social performance. Academy of Management Review, 4, 497-505.

Carroll, A. B., \& Shabana, K. M. (2010). The business case for corporate social responsibility: A review of concepts, research and practice. International Journal of Management Review, 12, 85-105.

Casali, G. L. (2011). Developing a multidimensional scale for ethical decision making. Journal of Business Ethics, 104, 485-497.

Cheah, E.-T., Jamali, D., Johnson, J. E. V., \& Sung, M.-C. (2011). Drivers of corporate social responsibility attitudes: The demography of socially responsible investors. British Journal of Management, 22, 305-323.

Chidambaram, L., \& Tung, L. L. (2005). Is out of sight, out of mind? An empirical study of social loafing in technology-supported groups. Information Systems Research, 16(2), 149-160.

Cohen, S. G., \& Bailey, D. E. (1997). What makes teams work: Group effectiveness research from the shop floor to the executive suite. Journal of Management, 23, 239-290.

Cohen, J., Cohen, P., West, S. G., \& Aiken, L. S. (2003). Applied multiple regression/correlation analysis for the behavioral sciences. Mahwah, NJ: Lawrence Erlbaum.

Colquitt, J. A., Noe, R. A., \& Jackson, C. L. (2002). Justice in teams: Antecedents and consequences of procedural justice climate. Personnel Psychology, 55, 83-109.

Colquitt, J. A., \& Zapata-Phelan, C. P. (2007). Trends in theory building and theory testing: A five-decade study of the academy of management journal. Academy of Management Journal, 50, 1281-1303.

Costa, P. T., \& McCrae, R. R. (1992). Four ways five factors are basic. Personality and Individual Differences, 13, 653-665.

Crilly, D., Schneider, S. C., \& Zollo, M. (2008). Psychological antecedents to socially responsible behavior. European Management Review, 5, 175-190.

Cropanzano, R., \& Schminke, M. (2001). Using social justice to build effective work groups. In M. E. Turner (Ed.), Groups and work: theory and research (pp. 143-172). Mahwah, NJ: Lawrence Erlbaum.

De George, R. T. (2000). Ethics in international business: A contradiction in terms? Business Credit, 102(8), 50-52.

de Leeuw, J., \& Meijer, E. (2008). Handbook of multilevel analysis. New York: Springer.

DeVellis, R. F. (2012). Scale development. Theory and applications. Thousand Oaks, CA: Sage.

Donaldson, T., \& Preston, L. E. (1995). The stakeholder theory of the corporation: Concepts, evidence, and implications. Academy of Management Review, 20, 65-91.

Etheredge, J. M. (1999). The perceived role of ethics and social responsibility: An alternative scale structure. Journal of Business Ethics, 18, 51-64.
Farrell, A. M. (2010). Insufficient discriminant validity: A comment on Bove, Pervan, Beatty, and Shiu (2009). Journal of Business Research, 63, 324-327.

Freeman, R. E., \& Liedtka, J. (1991). Corporate social responsibility: A critical approach. Business Horizons, 34(4), 92-98.

Freeman, E. R., Wicks, A. C., \& Parmar, B. (2004). Stakeholder theory and 'the corporate objective revisited'. Organization Science, 15(3), 364-369.

Friedman, M. (1970). The social responsibility of business is to increase its profits, New York Times Magazine, 13 September 1970.

Garcia de los Salmones, M. D. M., del Bosque, I. R., \& Crespo, A. H. (2005). Influence of corporate social responsibility on loyalty and valuation of services. Journal of Business Ethics, 61, $369-385$

Garriga, E., \& Melé, D. (2004). Corporate social responsibility theories: Mapping the territory. Journal of Business Ethics, 53, 51-71.

Gino, F., \& Moore, D. A. (2007). Effects of task difficulty on use of advice. Journal of Behavioral Decision Making, 20, 21-35.

Glavas, A., \& Piderit, S. K. (2009). How does doing good matter? Effects of corporate citizenship on employees. Journal of Corporate Citizenship, 36, 51-70.

Goldfried, M. R., \& d'Zurilla, T. J. (1969). A behavioural analytics model for assessing competence. In C. D. Spielberger (Ed.), Current topics in clinical and community psychology (Vol. 1, pp. 151-196). New York: Academic Press.

Gough, H. G., McCloskey, H., \& Meehl, P. E. (1952). A personality scale for social responsibility. Journal of Abnormal and Social Psychology, 47, 73-80.

Greening, D. W., \& Gray, B. (1994). Testing a model of organizational response to social and political issues. Academy of Management Journal, 37, 467-498.

Greening, D. W., \& Turban, D. B. (2000). Corporate social performance as a competitive advantage in attracting a quality workforce. Business and Society, 39, 254-280.

Gully, S. M., Phillips, J. M., Castellano, W. G., Han, K., \& Kim, A. (2013). A mediated moderation model of recruiting socially and environmentally responsible job applicants. Personnel Psychology, 66(4), 935-973.

Harris, D. B., Clark, K. E., \& Rose, A. M. (1954). The measurement of responsibility in children. Child Development, 25, 21-28.

Harter, J. K., Schmidt, F. L., \& Hayes, T. L. (2002). Business-unitlevel relationship between employee satisfaction employee engagement, and business outcomes: A Meta-analysis. Journal of Applied Psychology, 87, 268-279.

Harvey, N., \& Fisher, I. (1997). Taking advice: accepting help, improving judgment, and sharing responsibility. Organizational Behavior and Human Decision Processes, 70, 117-133.

Hausman, J. A. (1978). Specification tests in econometrics. Econometrica, 46, 1251-1271.

Hillenbrand, C., Money, K., \& Ghobadian, A. (2011). Unpacking the mechanism by which corporate responsibility impacts stakeholder relationship. British Journal of Management, 24, 127-146.

Hofmann, D. A. (1997). An overview of the logic and rationale of hierarchical linear models. Journal of Management, 23, 723-744.

Ibrahim, N. A., Howard, D. P., \& Angelidis, J. P. (2008). The relationship between religiousness and corporate social responsibility orientation: Are there differences between business managers and students? Journal of Business Ethics, 78(1-2), 165-174.

Jackson, D. N., Paunonen, S. V., \& Tremblay, P. F. (2000). Six factor personality questionnaire manual. Port Huron, MI: Sigma Assessment Systems. 
Jones, D. A. (2010). Does serving the community also serve the company? Using organizational identification and social exchange theories to understand employee responses to a volunteerism programme. Journal of Occupational and Organizational Psychology, 83, 857-878.

Jones, D. A., Willness, C., \& Madey, S. (2014). Why are job seekers attracted by corporate social performance? Experimental and field tests of three signal-based mechanisms. Academy of Management Journal, 57(2), 383-404.

Judge, T. A., Higgins, C. A., Thoresen, C. J., \& Barrick, M. R. (1999). The Big Five personality traits, general mental ability, and career success cross the life span. Personnel Psychology, 52, 621-652.

Karau, S. J., \& Williams, K. D. (1993). Social loafing: a meta-analytic review and theoretical integration. Journal of Personality and Social Psychology, 65, 681-706.

Kenny, D. A., Mannetti, L., Pierro, A., Livi, S., \& Kashy, D. A. (2002). The statistical analysis of data from small groups. Journal of Personality and Social Psychology, 83, 126-137.

Kerr, N. L., \& Tindale, R. S. (2004). Group performance and decision making. Annual Review of Psychology, 55, 623-655.

Kim, H., Lee, M., Lee, H., \& Kim, N. (2010). Corporate social responsibility and employee company identification. Journal of Business Ethics, 95(4), 557-569.

Kolodinsky, R. W., Madden, T. M., Zisk, D. S., \& Henkel, E. T. (2010). Attitudes about corporate social responsibility: Business student predictors. Journal of Business Ethics, 91, 167-181.

Kunda, Z. (1999). Social cognition. Making sense of people. Cambridge, MA: MIT Press.

Küskü, F., \& Zarkada-Fraser, A. (2004). An empirical investigation of corporate citizenship in Australia and Turkey'. British Journal of Management, 15, 57-72.

Levine, J. M., \& Moreland, R. L. (1990). Progress in small group research. Annual Review of Psychology, 41, 585-634.

Levine, J. M., \& Moreland, R. L. (1994). Group socialization: Theory and research. In W. Stroebe \& M. Hewstone (Eds.), European review of social psychology (Vol. 5, pp. 305-336). Chichester: Wiley.

Li, A., \& Cropanzano, R. (2009). Fairness at the group level: justice climate and intra-unit justice climate. Journal of Management, 35, 564-599.

Lim, S., \& Phillips, J. (2008). Embedding CSR values: The global footwear industry's evolving governance structure. Journal of Business Ethics, 81(1), 143-156.

Lin, C., Lyau, N., Tsai, Y., Chen, W., \& Chiu, C. (2010). Modeling corporate citizenship and its relationship with organizational citizenship behaviors. Journal of Business Ethics, 95, 357-372.

Lowry, P., Roberts, T. L., Romano, N. C, Jr, Cheney, P. D., \& Hightower, R. T. (2006). The impact of group size and social presence on small-group communication. Small Group Research, 37(6), 631-661.

Lyons, D. (1976). Ethical relativism and the problem of incoherence. Ethics, 86, 107-121.

Magnani, L. (2007). Morality in a technological world: Knowledge as a duty. New York: Cambridge University Press.

Magnani, L. (2009). Abductive cognition: The epistemological and eco-cognitive dimensions of hypothetical reasoning. Berlin: Springer.

Maignan, I. (2001). Consumer perceptions of the corporate social responsibility: A cross cultural comparison. Journal of Business Ethics, 30, 57-73.

Maignan, I., Ferrell, O. C., \& Hult, G. T. M. (1999). Corporate citizenship: Cultural antecedents and business benefits. Journal of the Academy of Marketing Science, 27, 455-469.

March, J. G. (1994). A primer on decision making. New York: Free Press.
Mathisen, G. E., Ogaard, T., \& Marnburg, E. (2013). Women in the boardroom: How do female directors of corporate boards perceive boardroom dynamics? Journal of Business Ethics, 116, 87-97.

McDonald, R. P. (1999). Test theory: A unified treatment. Mahwah, NJ: Erlbaum.

McWilliams, A., \& Siegel, D. S. (2011). Creating and capturing value: Strategic corporate social responsibility, resource-based theory, and sustainable competitive advantage. Journal of Management, 37, 1480-1495.

Miles, J. R., \& Kivlighan, D. R. (2012). Perceptions of group climate by social identity group in intergroup dialogue. Group Dynamics: Theory, Research, and Practice, 16, 189-205.

Moreland, R. L., \& Levine, J. M. (1982). Socialization in small groups: Temporal changes in individual group relations. In L. Berkowitz (Ed.), Advances in Experimental Social Psychology (Vol. 15, pp. 137-192). New York: Academic Press.

Moreland, R. L., \& Levine, J. M. (2002). Socialization and trust in work groups. Group Processes \& Intergroup Relations, 5, 185-201.

Moreland, R. L., Levine, J. M., \& Wingert, M. L. (1996). Creating the ideal group: Composition effects at work. In E. H. Witte \& J. H. Davis (Eds.), Understanding group behavior. Small group processes and interpersonal relations: Understanding group behavior (Vol. 2, pp. 11-35). Hillsdale, NJ: Lawrence Erlbaum.

Mudrack, P. (2007). Individual personality factors that affect normative beliefs about the rightness of corporate social responsibility. Business \& Society, 46, 33-62.

Muller, A., \& Kolk, A. (2010). Extrinsic and intrinsic drivers of corporate social performance: Evidence from foreign and domestic firms in Mexico. Journal of Management Studies, 47, $1-26$.

Muthuri, J. N., Matten, D., \& Moon, J. (2009). Employee volunteering and social capital: contributions to corporate social responsibility. British Journal of Management, 20, 75-89.

Nakamura, M., \& Watanabe-Muraoka, A. M. (2006). Global social responsibility: Developing a scale for senior high school students in Japan. International Journal for the Advancement of Counseling, 28, 213-226.

Nishii, L. H. (2013). The benefits of climate for inclusion for genderdiverse groups. Academy of Management Journal, 56(6), 1754-1774.

Nunnally, J. C. (1978). Psychometric theory. New York: McGrawHill.

Ormiston, M., \& Wong, E. M. (2013). License to ill: the effects of corporate social responsibility and CEO moral identity on corporate irresponsibility. Personnel Psychology, 66(4), $861-893$

Park, H. (2005). The role of idealism and relativism as dispositional characteristics in the socially responsible decision-making process. Journal of Business Ethics, 56, 81-98.

Payne, J. W., Bettman, J. R., \& Johnson, E. J. (1993). The adaptive decision maker. New York, NY: Cambridge University Press.

Pierce, C. S. (1955). Abduction and induction. In C. S. Peirce \& J. Buchler (Eds.), Philosophical writings of Pierce (pp. 150-156). New York, NY: Dover.

Podsakoff, P. M., MacKenzie, S. B., \& Podsakoff, N. P. (2012). Sources of method bias in social science research and recommendations on how to control it. Annual Review of Psychology, $63,539-569$.

Porter, M. E., \& Kramer, M. R. (2002). The competitive advantage of corporate philanthropy. Harvard Business Review, 80(12), 56-69.

R Core Team (2015). R: A language and environment for statistical computing. Vienna: R Foundation for Statistical Computing 
Ramus, C. A., \& Steger, U. (2000). The roles of supervisory support behaviors and environmental policy in employee "ecoinitiatives" at leading-edge European companies. Academy of Management Journal, 43, 605-626.

Raudenbush, S. W., \& Bryk, A. S. (2002). Hierarchical linear models: Applications and data analysis methods. Thousand Oaks, CA: Sage.

Reidenbach, R. E., \& Robin, D. P. (1990). Toward the development of a multidimensional scale for improving evaluations of business ethics. Journal of Business Ethics, 9, 639-653.

Rescher, N. (1987). Ethical idealism. Berkeley and Los Angeles, CA: University of California Press.

Rodrigo, P., \& Arenas, D. (2008). 'Do employees care about CSR programs? A typology of employees according to their attitudes. Journal of Business Ethics, 83, 265-283.

Roth, P. L. (1994). Missing data: A conceptual review for applied psychologists. Personnel Psychology, 47, 537-560.

Rupp, D. E. (2011). An employee-centered model of organizational justice and social responsibility. Organizational Psychology Review, 1, 72-94.

Rupp, D. E., Ganapathi, J., Aguilera, R. V., \& Williams, C. A. (2006). Employee reactions to corporate social responsibility: An organizational justice framework. Journal of Organizational Behavior, 27, 537-543.

Rupp, D. E., \& Mallory, D. B. (2015). Corporate social responsibility: Psychological, person-centric, and progressing. Annual Review of Organizational Psychology and Organizational Behavior, 2, 211-236.

Rupp, D. E., Shao, R., Thornton, M. A., \& Skarlicki, D. P. (2013). Applicants' and employees' reactions to corporate social responsibility: The moderating effects of first-party justice perceptions and moral identity. Personnel Psychology, 66(4), 895-933.

Saks, A. M. (2006). Antecedents and consequences of employee engagement. Journal of Managerial Psychology, 21, 600-619.

Schneider, B. (1975). Organizational climate: An essay. Personnel Psychology, 28, 447-479.

Secchi, D. (2007). Utilitarian, managerial, and relational theories of corporate social responsibility. International Journal of Management Reviews, 9, 347-373.

Secchi, D. (2009). The cognitive side of social responsibility. Journal of Business Ethics, 88(3), 565-581.

Secchi, D. (2011). Extendable rationality. Understanding decision making in organizations. New York: Springer.

Secchi, D. (2012). The social responsibilities of the individual: Towards a theoretical framework. In Academy of Management Conference. Boston, MA, USA.

Senge, P. M. (2006). The fifth discipline: The art and practice of the learning organization (2nd ed.). London: Random House.

Shawver, T., \& Sennetti, J. (2009). Measuring ethical sensitivity and evaluation. Journal of Business Ethics, 88(4), 663-678.

Shen, W., Kiger, T. B., Davies, S. E., Rasch, R. L., Simon, K. M., \& Ones, D. S. (2011). Samples in applied psychology: Over a decade of research in review. Journal of Applied Psychology, 96, $1055-1064$.

Shepperd, J. A., \& Wright, R. A. (1989). Individual contributions to a collective effort: An incentive analysis. Personality and Social Psychology Bulletin, 15, 141-149.
Singhapakdi, A., Vitell, S. J., Rallapalli, K. C., \& Kraft, K. L. (1996). The perceived role of ethics and social responsibility: A scale development. Journal of Business Ethics, 15, 1131-1140.

Sniezek, J. A., Schrah, G. E., \& Dalal, R. S. (2004). Improving judgment with prepaid expert advice. Journal of Behavioral Decision Making, 17, 173-190.

Starrett, R. H. (1996). Assessment of global social responsibility. Psychological Reports, 78, 535-554.

Stasio, M. J., \& Capron, E. W. (1998). Social interest as a distinct personality construct: Comparisons with "the big five" and related prosocial constructs. Journal of Individual Psychology, $54,10-23$.

Staw, B. M., \& Cohen-Charash, Y. (2005). The dispositional approach to job satisfaction: More than a mirage, but not yet an oasis. Journal of Organizational Behavior, 26(1), 59-78.

Steiner, I. (1972). Group process and productivity. New York: Academic Press.

Sully de Luque, M. S., Washburn, N. T., Waldman, D. A., \& House, R. J. (2008). Unrequited profit: How stakeholder and economic values relate to subordinates' perceptions of leadership and firm performance. Administrative Science Quarterly, 53, 626-654.

Thagard, P. (2012). The cognitive science of science. Cambridge, MA: MIT Press.

Trevino, L. K. (1986). Ethical decision making in organizations: A person-situation interactionist model. Academy of Management Review, 11(3), 601-617.

Turban, D. B., \& Greening, D. W. (1997). Corporate social performance and organizational attractiveness to prospective employees. Academy of Management Journal, 40, 658-673.

Valacich, J. S., Wheeler, B., Mennecke, B., \& Wachter, R. (1995). The effects of numerical and logical size on computer-mediated idea generation. Organizational Behavior and Human Decision Processes, 62, 318-329.

Van Dierendonck, D. (2011). Servant leadership: A review and synthesis. Journal of Management, 37(4), 1228-1261.

Van Marrewijk, M. (2003). Concept and definitions of CSR and corporate sustainability: Between agency and communion. Journal of Business Ethics, 44, 95-105.

Watson, D. \& Clark, L. A. (1994). The PANAS-X. Manual for the positive and negative affect schedule-expanded form. The University of Iowa. Retrieved online at http://www.psychology. uiowa.edu/faculty/Clark/PANAS-X.pdf; 28 December 2011.

Weick, K. E., \& Roberts, K. H. (1993). Collective mind and organizational reliability: The case of flight operations on an aircraft carrier deck. Administrative Science Quarterly, 38, $357-381$.

Windsor, D. (2001). The future of corporate social responsibility. International Journal of Organizational Analysis, 9, 225-256.

Witt, L. A., \& Silver, N. C. (1994). The effects of social responsibility and satisfaction on extrarole behaviors. Basic and Applied Social Psychology, 15(3), 329-338.

Zinbarg, R. E., Revelle, W., Yovel, I., \& Li, W. (2005). Cronbach's Alpha Revelle's Beta, McDonald's Omega: Their relations with each and two alternative conceptualizations of reliability. Psychometrika, 70, 123-133. 